\title{
APARENTAR(-SE) A OUTRO: \\ ELEMENTOS PARA UMA POÉTICA PERSPECTIVISTA ${ }^{1}$
}

\author{
KIN-SEEMING (TO) OTHERS: \\ TOWARDS A PERSPECTIVIST POETICS
}

\author{
Alexandre Nodari (species/UFPR/CNPq) \\ alexandre.nodari@gmail.com
}

\begin{abstract}
RESUMO: Busca-se repensar categorias da poética ocidental pelo seu contraste com poéticas ameríndias num exercício de equivocação e não de equivalência. Ou seja, investigar de que modo conceitos da teoria literária podem ser relidos (deslocados) a partir do contato entre práticas verbais de distintas ordens e naturezas. Isso comporta uma dificuldade prévia, sobre o estatuto do que chamamos de "literatura", que não corresponde ao(s) lugar(es) daquilo que se designa, de modo imperfeito, como poéticas indígenas: estas não se separam em uma esfera autônoma, não se dissociam de práticas como o xamanismo, o ritual, a exortação, a explicação cosmológica, e mesmo o entretenimento ou a literatura no sentido "branco", etc - são artes "multimodais". Qualquer equiparação comporta o perigo da redução e da violência, fazendo com que a comparação e a (con)tradução conceitual propostas sejam inviáveis se não forem acompanhadas de uma reflexão político-institucional sobre os lugares (do ter lugar) da linguagem.
\end{abstract}

PALAVRAS-CHAVE: perspectivismo; imitação; enunciação; multiposicionalidade.

\footnotetext{
${ }^{1}$ Parte significativa das ideias aqui apresentadas foram esboçadas em disciplinas de graduação e pós-graduação de literatura e filosofia na Universidade Federal do Paraná sobre poéticas ameríndias, o estatuto ontológico da experiência literária e de introdução ao estudo da poesia. Agradeço, portanto, aos estudantes que foram, de certa forma, cobaias involuntárias. Além disso, o texto reúne trechos de um ensaio escrito, a convite de Tiago Guilherme Pinheiro e Fabiano Calixto, para ser publicado no segundo número da revista meteöro, infelizmente cancelada por falta de recursos, e de uma apresentação feita no Simpósio "Cenografias da voz, ontografias do sentido", organizado por Roberto Zular, Lucius Provase e Fábio Roberto Lucas, no âmbito do XVI Congresso Internacional da Abralic, realizado em Brasília (UnB) em 2019. Devo muito do burilamento das formulações à interlocução com os participantes do Simpósio. Por fim, manifesto minha gratidão a todos que leram e comentaram comigo seja um desses dois textos, seja versões prévias ou em progresso do que agora se publica, em especial o grupo transdisciplinar Juridicidades nativas (Marcela Coelho de Souza, Andressa Lewandowski, Adriana Dias, Marcos Matos e Thiago Hoshino), Marília Lourenço, Guilherme Gontijo Flores e Pedro Cesarino.
} 
ABSTRACT: Can concepts pertaining to literary theory be read in another fashion through the contact between verbal arts of distinct order and nature? Is it possible to rethink some of the western poetics' categories equivocating them with their apparent analogous in ameridian poetics? In order to do so, we must face a difficulty related to the status of what "we" call "literature", which does not correspond to the place(s) occupied by what we call amerindian poetics: the latter doesn't pertain to and authonomous and separate sphere; as "multi-modal" arts, they don't distinguish themselves from practices such as xamanism, ritual, war exhortation, cosmological explanation, and even entertainment or literature in the sense of the "white people". Any equiparation brings with itself the risk of a violent reduction, obliging our comparsion and conceptual translations to be accompanied by a political-institutional reflextion about the places where language takes place.

KEYWORDS: perspectivism; imitation; enunciation; multiposicionality.

1. Radicalizando o laço paradoxal entre literatura e instituição, tal como concebido por Derrida (2014), talvez fosse possível dizer que só há literatura, enquanto um campo específico para um discurso em si mesmo inespecífico, nas sociedades com Estado: só há literatura (enquanto instituição mais ou menos demarcada) onde há Direito estatal. A razão disso talvez se relacione aos efeitos ou à eficácia da linguagem, à palavra eficaz, ou, em outras palavras, ao caráter performativo da linguagem. ${ }^{2}$ O Direito estatal parece ser uma (tentativa de) concentração (mas não monopólio) institucional da força ilocucionária da linguagem: o Estado, o Direito, individualiza em certos cargos ou funções, e práticas, o poder legítimo de emitir enunciados performativos. ${ }^{3}$ É interessante notar, nesse sentido, que os dois modos verbais privilegiados pelos quais o Direito estatal realiza tal poder, desde o direito romano arcaico, são, como aponta

\footnotetext{
${ }^{2}$ Os mitos ameríndios são, em certo sentido, um campo em que tal performatividade encontra-se plenamente disseminada, constituindo, assim, uma reflexão profunda, tanto na forma quanto no conteúdo, sobre a relação entre palavras e coisas. Desse modo, em muitos mitos, o nome já adianta a coisa que essa se tornará (como também na mitologia greco-romana: Narciso se torna a flor de mesmo nome; a ninfa Eco, o fenômeno acústico, etc.), em uma espécie de literalidade que muitas vezes se manifesta também no fato de que enunciar ou pensar algo é já fazê-lo. Para tomar exemplos aikewara, em um de seus mitos, a "moça chamada Cutia" se tornará a espécie cutia, e, em outro, "a Mucura que, a princípio, mentiu sobre suas necessidades fisiológicas tornou-se incapaz de contê-las": de tanto dizer que estava com vontade de urinar e defecar para escapulir da dança ritual, ela "realmente sentiu vontade de defecar e (...) o fez na frente de todos, enquanto dançava" (CALHEIROS, 2014, p. 48, 40).

${ }^{3}$ Como se sabe, nas conferências reunidas sob o título How to do things with words (Quando dizer é fazer, na tradução brasileira), Austin (1990) parte de uma distinção tipológica entre enunciados constativos e performativos (sendo que os exemplos dos últimos são jurídico-institucionais: nomeação, casamento, etc.), para, depois, abandoná-la em favor de uma visão mais fluida em que todo ato de fala é, ao mesmo tempo, locucionário ("constativo", diríamos), ilocucionário ("performativo", diríamos) e perlocucionário (uma espécie de terceiro termo entre um e outro, ligado à persuasão). $\mathrm{O}$ que estamos querendo apontar é que, embora, por um lado, em nossa sociedade, de fato, todo ato de fala contenha essas três forças (ou aspectos) da linguagem, por outro, há uma esfera, a do Direito, que visa concentrar (e mesmo tentar capturar) o caráter ilocucionário sob a forma de enunciados performativos em sentido estrito e de eficácia tendencialmente máxima.
} 
Magdelain (1990, p. XI), o imperativo e a primeira pessoa: por um lado, a ordem e o comando, e, por outro, o enunciado performativo em sentido estrito. Assim, as três palavras solenes do direito romano arcaico são do, dico, addico (dou, digo, sentencio). É evidente que essa tentativa de concentrar a força da linguagem de fazer coisas, ou seja, a sua força poiética, não implica um controle absoluto - não implica que esta não se estenda para fora do Direito estatal, mas sim que sua normatização e direcionamento gera uma verticalização, uma hierarquização da poiesis da palavra. Num polo superior, encontraríamos a linguagem dotada de eficácia máxima: a palavra estatal juridicamente autorizada. No inferior, aquela dotada de eficácia mínima: a literatura. Um não existe sem o outro.

2. “A liberdade de dizer tudo", diz Derrida (2014, p. 53) sobre a literatura, "é uma arma política muito poderosa, mas pode imediatamente se deixar neutralizar como ficção". O próprio conceito moderno de ficção constitui, assim, uma faca de dois gumes, pois o poder ou direito de tudo dizer, característico da literatura enquanto uma instituição ${ }^{4}$, traz consigo um risco: o risco de que não produza riscos, já que se trata de um discurso sem a efetividade "prática" dos outros (não só o jurídico, mas o científico, o jornalístico, cujo poder perlocucionário é evidente, etc.). É como se a "poesia" fosse algo como uma paródia do Direito estatal (da poiesis): nela, a palavra eficaz (capaz de criar inclusive mundos) não é eficaz (os mundos que cria estão "fora" deste mundo, não têm efeitos diretos sobre ele). Esse paradoxo - o de poder dizer tudo mas em nada poder ter efeitos - deriva do embate com a censura que institucionalizou a literatura (e a arte de um modo mais geral) enquanto um espaço discursivo distinto dos demais (o que se percebe até fisicamente, nos museus, ou nas prateleiras de uma biblioteca ou de uma livraria): para fugir aos seus tentáculos, os escritores sublinhavam que estavam ficcionalizando. ${ }^{5}$ Alguns (muitos) artistas e teóricos se mostraram cientes dos perigos dessa "liberdade" literária, e é tal consciência, inclusive, que mobiliza as vanguardas e seu desejo de fundir ou aproximar arte e vida (política), sair dos museus e dos lugares físicos ou institucionais. Assim, Döblin (citado por Pimenta, 1976, p. 10), de modo sintético, apontará que “"A arte é livre', quer dizer, é totalmente inofensiva". E Marc Shell (1993, p. 150), de forma mais estendida, dirá que

\footnotetext{
${ }^{4}$ Até pouco tempo atrás, "literatura" designava o conjunto da produção escrita, de textos escritos, ficcionais ou não - acepção ainda usada quando falamos, por exemplo, na "literatura médica" sobre determinado assunto.

${ }^{5}$ Para dar um exemplo hiperconhecido: as Cartas chilenas. Como afirma Anabel Patterson (1991, p. 4), em um argumento extensível à arte como um todo, "é, em parte, à censura que devemos nosso próprio conceito de 'literatura', como um tipo de discurso com suas próprias regras, um conceito que, por séculos, foi ideado como sendo capaz de proteger escritores que tentaram conformar-se àquelas regras”. Cf. Nodari (2012).
} 
O grande perigo para a literatura não é o argumento de que ela subverte os cidadãos ao ensinar-lhes inverdades; é o argumento, implícito ou explícito, de que ela não tem valor real ou potencial para afetar o bem ou o mal, que ela não possui nenhum papel real nos assuntos humanos e não deve ser tomada seriamente.

Do mesmo modo que o poder poiético da linguagem foi (tendencialmente) concentrado na esfera jurídica, o seu caráter poético o foi na literatura (e se poderia dizer, invertendo uma afirmação que fizemos, que a linguagem jurídica, o juridiquês, é uma paródia da poesia: nela a palavra poética não é poética). Todavia, como se sabe, não há nada que caracterize a literatura como um discurso específico: nem uma suposta literariedade (que pode estar presente em qualquer fala ou escrita, inclusive a conversa cotidiana), nem um conjunto de formas (até mesmo um documento jurídico, como um testamento, pode ser/se tornar um texto de literatura) - nada a não ser a sua inscrição institucional define uma obra literária. A difundida imagem da arte como "reserva ecológica", seja do pensamento selvagem dentro do domesticado (LÉVISTRAUSS, 1989, p. 245), seja do não conversível em mercadoria ou do inutensílio dentro do capitalismo e do utilitarismo moderno (LEMINSKI, 1987, p. 291), aponta para como um atributo disseminado através da praxis linguística foi cercado e cerceado, para como a esse nãolugar foi atribuído um lugar.

3. Uma outra forma de dizer isso é que a magia é convertida em ficção. Num duplo sentido: por um lado, a magia entendida como poiesis, como capacidade transformadora da linguagem, passa a ser "mera ficção"; por outro, tal performatividade capaz de refazer o mundo se institucionaliza na forma da ficção jurídica, instrumento por excelência do Direito estatal, sua fonte e origem. Ainda não se deu a devida importância nem se extraiu todas as consequências do fato de que a noção de "ficção" foi primeiro e mais profundamente conceitualizada, explorada e mobilizada no campo jurídico, por meio da fictio iuris, antes de se tornar (e a partir do qual se tornou) a categoria estética que define hoje o campo do que chamamos de literatura, em mais uma evidência do laço entre a Instituição (o Estado) e a institucionalização da arte. Definida por Yan Thomas (1995, p. 44) como o "poder de fazer, desfazer ou modificar, ou de quase fazer, quase desfazer, e quase modificar a substância e suas modalidades", a ficção jurídica consiste em "travestir os fatos, em declará-los diferentes do que eram verdadeiramente, e em extrair desta adulteração mesma e desta suposição falsa as consequências jurídicas que seriam próprias à verdade assim simulada, se ela houvesse existido artificialmente" (THOMAS, 1995, p. 17). Todavia, para operar, a fictio iuris deve, simultaneamente, separar o verdadeiro do falso, criar uma descontinuidade entre ambos, para poder, no mesmo gesto, re-uni-los, dando 
ao falso a eficácia da realidade, dando à mentira um efeito de verdade - isto é, a performatividade da linguagem deve assumir a sua artificialidade, tornar-se artifício, separarse do mundo (para assim transformá-lo): "a ficção requer (...) a certeza do falso", "é uma negação manifesta do verdadeiro" (THOMAS, 1995, p. 17-18). Ou, na formulação medieval de Baldo: ela consiste em "tomar o falso por verdadeiro" (falsitas pro veritate accepta) (THOMAS, 1995, p. 17). A transformação poiética se converte, assim, em artifício jurídico. Discretizadas, verdade e mentira, a palavra e seus efeitos, dependem agora da mediação de um terceiro termo para se encontrarem. De outro lado, a ficção literária se revela uma mentira com efeitos, mas sem efeitos, puro artifício. ${ }^{6}$

4. De outro lado, todos conhecemos a famosa descrição clastreana da instituição da chefia entre os povos contra o Estado, em que tal verticalização aparece invertida: a fala do chefe não é dotada de eficácia, de poder performativo - antes, é emitida para ser contestada, ignorada. Além disso, é difícil encontrar entre esses povos a presença de enunciados performativos no registro da política no sentido estrito e institucional em que estamos acostumados a concebê-la, embora, sim, no campo do xamanismo ou da feitiçaria, o qual, porém, não se organiza de forma vertical e institucional, mas transversal e disseminado (VIVEIROS DE CASTRO, 2015, p. 171-181). Aqui, a força ilocucionária da linguagem encontra-se dissolvida e espalhada pelo socius (e mesmo pelo cosmos), e a palavra poiética não se separa em um polo de máxima e outro de mínima eficácia. De maneira análoga, nos deparamos com o fato de em tais sociedades as artes verbais serem multimodais (CESARINO, 2018), i.e., não constituírem uma modalidade discursiva específica como na nossa, não se separarem de outras práticas, além de ser patente, em suas línguas, a inexistência de termos correspondentes ao que chamamos de ficção - o que não quer dizer, evidentemente, que não se efetuem distinções pragmáticas dentre o amplo espectro que vai do verdadeiro ao falso (pense-se na ideia yanomami de metáfora como uma

\footnotetext{
${ }^{6}$ Para uma história literária do conceito de ficção (i.e., uma história interna do conceito dentro das obras e debates literários), cf. Stierle (2006). Todavia, ao contrário do que ele aponta, o direito não foi uma aplicação ou desenvolvimento particular da ficção e de seu conceito, mas o lugar mesmo, já na Roma antiga, em que ela foi definida conceitualmente, inclusive em seus contornos e limites. É verdade que Ovídio e Horário (e muitos outros), como Stierle argumenta, falam em ficções, falam das ficções, mas falam acima e sobretudo da ação de "fingir", fingere, verbo de uma enorme amplitude semântica em latim, da qual nos restou majoritariamente a acepção empobrecida e depreciativa de enganar, pretender ser - talvez apenas finta tenha preservado algo das significações positividas do fingimento. "Fingere", diz Stierle (2006, p. 12 e ss), indica plasmar, moldar a partir de um material, ou então a criação de ilusões, mas o substantivo fictio possui já no direito romano antigo (prévio a Ovídio e Horácio) uma acepção mais precisa (com a qual eles também jogam), que irá, adaptando-se à cosmologia cristã medieval, contaminar, na Renascença, a esfera artística. O que estamos querendo afirmar é que a definição atual mais corrente de ficção deriva dessa de cunho jurídico, embora desjuridificada, como se aquilo que chamamos de ficção tivesse sido moldado pelo direito, fosse ainda em certo sentido fictio iuris, mas sem seu poder transformador.
} 
“mentira que não engana”, segundo José Kelly [2015, p. 50]). Não é que não haja em absoluto Direito nem literatura - é que tanto a juridicidade quanto a poesia são transversais. A recusa ao Estado é também uma recusa ao estado da arte.

5. Ou seja, se por um lado o direito se origina (ou se aproxima) da magia pelo caráter performativo da linguagem, pelo uso de fórmulas e de uma linguagem ritual (o juridiquês, que não é um adendo eliminável do direito, mas parte constitutiva dele), por outro, ele a transforma em outra coisa (ou se afasta dela) ao se autoconceber como ficção e amparar a sua efetividade na ideia de que a fictio que ele é deve ser tomada como verdadeira (cf. NODARI, 2013), i.e., precisa ser aplicada no mundo: enforced. O performativo jurídico deve ser (re)forçado pelo aparato estatal, de modo que ter força-de-lei implica a necessidade de um reforço, o que é visível na separação jurídica entre processo de conhecimento, que decide sobre a causa, e processo de execução, que aplica tal decisão, que lhe dá eficácia de fato, que a cumpre. Talvez se possa dizer, mais propriamente, que é o direito que produz a cisão entre a forma (palavra) e a força (ação), poesia e poiesis, falar e fazer, de modo que o performativo jurídico (o exemplo por excelência de Austin) é um pseudo-performativo, pois necessita de um suplemento originário, como diria Derrida. A magia (ao menos na forma do xamanismo ameríndio, que é nosso horizonte aqui) carece desse reforço: cumpre-se por si só, embora possa recorrer a auxílios materiais (plantas, objetos) e espirituais. Nela, palavra e ação, embora possam ser descritivamente dissociados, constituem um único evento que se desdobra em dois planos reversíveis (quer seja o do falar e do fazer, quer seja o desse mundo e o do outro, em que se desenrola a outra cena, o anverso da cena visível daqui). $\mathrm{O}$ equivalente no plano histórico da literalidade do plano mítico, em que dizer já é fazer, é o caráter reversível da narratividade das artes verbais xamânicas: o "narrar como um evento" (CESARINO, 2006, p. 111). O xamã "narra o vivido e vive o narrado", para usar a formulação de Walnice Nogueira Galvão (1972, p. 12) sobre Riobaldo: assim, por um lado, diz Cesarino, o pajé "relata, reporta e torna visíveis seus trajetos" (CESARIANO, 2006, p. 107), e, por outro, para usar a expressão de um xamã Yaminawa citado por Townsley (1993, p. 454), “cantos são caminhos".7 “Alguns”, continua, "me levam por uma via curta - alguns me levam por uma via longa - eu os deixo retos e ando neles - eu os olho enquanto vou - nem uma coisa sequer escapa da minha atenção - eu chamo mas eu continuo no caminho" (TOWNSLEY, 1993, p. 454). Tomemos, como exemplo, um

\footnotetext{
${ }^{7}$ Do mesmo modo, comenta Cesarino (2006, p. 107) a respeito de cantos huni kuĩ, "os huni muka são propriamente caminhos".
} 
cântico de cura khĩsêtjê ${ }^{8}$ que Seeger $(2015$, p. 84) classifica como de invocação, em que se trata "da inserção do atributo de um animal, planta ou outro objeto natural no corpo humano, de modo a conferir uma propriedade do animal a uma parte ou função corporal particular": "invocava-se algo que os humanos não possuem, e o atributo era soprado e cantado no corpo do paciente". No caso em questão, a

invocação para habilitar crianças pequenas a comerem alimentos à base de mandioca sem passarem mal nomeava o porco-do-mato, que é capaz de comer mandioca-brava, venenosa, sem sofrer os efeitos deletérios. Quando a criança se tornasse, sob esse aspecto, um pouco como o porco, seria também capaz de comer da mandioca sem dificuldades - ao menos a preparada. (SEEGER, 2015, p. 84).

$\mathrm{O}$ canto, para se referir às qualidades do porco, narra o que este faz ("O caititu vai, como ele pode comer um pouco e sair? / Mastiga raízes, mastiga raízes, bebe o sumo, termina e vai, como pode? / Um animal, um animal, não é aquilo um animal / Como um mestre do comer, ele bebe e não faz mal"), ou seja, a ação relacionada à qualidade desejada, bem como sua chegada e partida do corpo da criança ("indo embora", "ele vai”) (SEEGER, 2015, p. 87). Não é um acaso, assim, que Dennis Tedlock (1975, p. 725) tenha apontado que as artes verbais ameríndias se deixam caracterizar melhor como poesia dramática: não se trata de uma prosa que remete a eventos passados, mas de uma dicção poética sobre eventos atuais (mesmo quando passados, eles são atualizados pela narrativa), ou seja, um drama poético, uma ação falada ao mesmo tempo que uma fala que age - ação poética. Tal narratividade performativa se coliga ainda a mais um fator: se, nos mundos ameríndios, animistas ou de agência distribuída pelo cosmos, toda doença ou evento é causado por alguém, então "conhecer é personificar" (VIVEIROS DE CASTRO, 2002, p. 358), subjetivar e não objetivar: conhecer o sujeito da ação, de modo a curar ou transformar algo, alguém ou um acontecimento, implica personificar, conhecer esse sujeito causador, sua história, sua vida, a história de sua formação, de seus feitos, para poder transformá-lo ou agir sobre ele. ${ }^{9}$ Conhecer implica, portanto, converter o que se quer

\footnotetext{
${ }^{8}$ Nas citações de Seeger, atualizei a grafia do etnônimo em questão, substituindo kĩsêdjê por khĩsêtjê.

${ }^{9}$ Cf. Cesarino, 2015. Como tentei mostrar alhures (Cf. NODARI, 2020a), Mário de Andrade estava ciente dessa concepção indígena e a mobilizou para produzir uma forte crítica à objetivação capitalista. Essa premissa ontológico-epistemológica também explica o recurso ao mito (ao tempo em que as "coisas" atuais eram sujeitos) como explicação e modo de conhecimento. Orlando Calheiros (2015, p. 14), em sua etnografia dos Aikewara, comenta: "não é de se estranhar que inquiridos sobre seus costumes, sobre o mundo e seus motivos, era comum que meus amigos, sobretudo os mais velhos, divagassem até encontrar em seu repertório uma se'eng-kwera, a qual, explicavam, continha a resposta (...). Aprendi com Awasa'i que para tudo aquilo que existe sobre a superfície da Ywyeté (a terra em que vivemos todos, a 'Terra-que-é-dura'), existe uma se'eng-kwera (lit. 'fala-de-outrora'), um mito, que com ela forma um 'par' (irutehé'hyga). Uma relação que vai além da parábola, alcançando aquilo que sua esposa, Muretama, definia em bom português como uma 'tradução'. Dizia-me que, da mesma maneira que ela traduzia as palavras de seu marido para o meu idioma, a se'eng-kwera traduzia tudo aquilo que existia nesse
} 
conhecer em narrativa, relato, história: para agir sobre algo pela linguagem (xamanismo), é preciso que este se inscreva na linguagem da ação (mito, narrativa) - talvez o caso mais conhecido na literatura etnográfica seja o canto de cura Cuna, analisado por Lévi-Strauss (2008) em “A eficácia simbólica”, no qual o pajé narra toda a trajetória anterior da paciente e do agente causador do mal, bem como o seu próprio percurso e ação curadora. E, por fim, para transformar o mundo pela linguagem, é preciso transformar a própria linguagem utilizada - daí o uso, na terapêutica xamânica, de barbarismos (palavras estrangeiras), arcaísmos e especialmente metáforas, ou seja, algo próximo daquilo que Aristóteles aconselhava para que os poetas adquirissem uma linguagem elevada em relação à ordinária (Poet. 1459a2-4, p. 183), com a diferença de que, no xamanismo, não se trata de elevar a linguagem à poesia (afastando-a da vida), mas de fazer coincidir poesia e poiesis.

6. A distinção, separação e demarcação da poiesis e da poesia, da linguagem performativa do Direito e do impoder ${ }^{10}$ da literatura, implica, do ponto de vista conceitual e operatório, uma diferenciação entre imitação e transformação, entre a linguagem transformadora do Direito e a palavra imitativa da literatura. Em linhas gerais, parte significativa da história da reflexão poética do Ocidente, desde seus gestos fundadores, é uma tentativa de erigir e fortalecer essa separação. ${ }^{11}$ Assim, por exemplo, se na concepção platônica de mimesis, especialmente a do Livro III da República, ainda nos deparamos com um contínuo, no qual a imitação (poética) sempre arrisca se converter em (transform)ação (social), ameaça que deve ser policiada ${ }^{12}$, já em

\footnotetext{
mundo; ele não apenas descrevia a sua origem, mas que indicava também o seu sentido". Seria interessante pensar como a noção de tradução se transforma ao ser equiparada a um modo de relação entre mito e história.

${ }^{10}$ Embora o termo tenha conotações negativas, não estamos deixando completamente de lado seu aspecto positivo, visível no uso dele por Artaud (que rendeu uma vasta bibliografia, dentre a qual se deve destacar as reflexões a seu respeito de Blanchot, Deleuze e Derrida), mas também por Guimarães Rosa (2001: s.p.), em "A benfazeja": "Então, o cego Retrupé esbarra com o impoder da cegueira". Aqui, a cegueira não é descrita como uma falta, uma negatividade ou passividade da visão e/ou de seu portador, não é uma falta de poder de Retrupé: o impoder é $d a$ cegueira e é ativo. E mais, no contexto do conto, é uma forma ativa de impedir o exercício do poder violento de Retrupé, como, aliás, a benfazeja está o tempo inteiro fazendo, no serviço sujo de impedir, ou de impoderar o poder, a violência, matando o marido, cegando o filho, limpando a rua. De modo lapidar, ao se referir ao tipo de construções vocabulares de Rosa presente em "impoder" (mas também em "acronologia, antipesquisas, indestruir, inimaginar"...), Paulo Rónai (2001, s.p.) as chamou de "antonímias metafísicas": "abstrações opostas a fenômenos percebíveis pelos sentidos", que, contudo, aludem "a uma nova modalidade de ser ou de agir, a manifestações positivas do que não é". Seria preciso, portanto, pensar de modo positivo e ativo o impoder da literatura (e a figura do impoder de um modo geral), o que, porém, não tenho condições de fazer aqui.

${ }^{11}$ Devemos salientar que essa tentativa implica, por vezes, fortalecer ou mesmo produzir aquilo que combate. Ou seja, em termos derridianos, trata-se de uma conjuração no duplo sentido: por um lado, "o exorcismo mágico que (...) tende a expulsar o espírito maléfico", e, por outro, "a encantação mágica destinada a evocar, a fazer vir pela voz, a convocar um feitiço ou um espírito" (DERRIDA, 1994, p. 70, 62). Agradeço a Marcos Matos por ter me chamado a atenção para a importância de pontuar isso.
}

${ }^{12}$ Cf. Nodari (2012, p. 108 e ss; 2019, p. 13-14). 
Aristóteles, por meio da noção de verossimilhança, adequação ou probabilidade (eikos), o contínuo inicia seu processo de discretização, que terá seu ápice com a noção moderna de representação (político-jurídica, mas também estética), uma espécie de terceiro termo entre imitação e transformação, que possibilita controlar a passagem de uma a outra, mantendo-os separados. A conhecida definição aristotélica da poesia se dá pela sua diferenciação, enquanto mythos, enredo, trama - em suma, estória (com sentido), em relação à história (enquanto amontoado desordenado de eventos em sequência cronológica), e a imitação em jogo não é mais de modos de vida (mimesis bion), como em Platão, mas de ações (mimesis praxeos): "a tarefa do poeta não é a de dizer o que de fato ocorreu, mas o que é possível e poderia ter ocorrido segundo a verossimilhança" (Poet., 1451a39, p. 95). A verossimilhança, como já se cansou de argumentar, é o critério que garante uma lógica interna, como que fechando o corpo da literatura (ou fechando o corpo do mundo à literatura): o campo semântico de eikota (geralmente vertido por "verossímil") abarca acepções como o que se parece, que é semelhante, adequado, apropriado, plausível, conveniente. Aparentemente alheio ao sem-sentido dos eventos da história humana, o verossímil permite à poesia separar-se dela: assim, "Deve-se escolher, de preferência, o impossível que é verossímil ao possível não persuasivo (...). Com relação à poesia, é preferível o impossível que persuade ao possível que não persuade (...); é também verossímil que muitas coisas se passem contra o verossímil". ${ }^{13}$ Pero non troppo, pois a definição do que é conveniente ou adequado ou plausível não deixa de vir (ou de vir também) de fora (da obra), de modo que não há verossimilhança puramente interna, não há verossimilhança que também não seja externa: assim, a certa altura, Aristóteles irá dizer, enumerando quatro pontos sobre os "caracteres", que

Existe um "bom caráter" para cada gênero de personagem: com efeito, há um "bom caráter" de mulher e um de escravo, ainda que, desses, talvez o primeiro pertença a uma classe inferior e o segundo a uma classe totalmente abjeta. O segundo ponto a se visar é a conveniência; de fato, é possível atribuir coragem à caracterização da personagem, mas seria inconveniente atribuir coragem ou espírito destemido a uma mulher. (Poet. 1454a18-24, p.125-7).

A verossimilhança, o que é apropriado ou conveniente, se parece, portanto, com uma espécie de porta ou basculante, que tanto separa quanto permite reunir de forma controlada a poesia e o fazer, a palavra imitativa e as ações imitadas, o mythos e a história.

\footnotetext{
${ }^{13}$ Poet., 1460a27-28, p.195; 1461b10-12, p.209; 1456a24-25, p.155. 
7. Poderíamos arriscar dizer que boa parte do debate antigo sobre a mimese gira em torno dos distintos modos e medidas capazes de convertê-la em uma "semelhantização". Semblabliser, semelhantizar, neologismo de Fernand Deligny, indica o movimento de tornar o outro semelhante a si mesmo, i.e., semantizá-lo, dar sentido à estrangeiridade daquele/daquilo que resiste ao sentido (o horizonte de suas formulações é a práxis com autistas): não assemelhar-se $a$ outro, mas assemelhar - assimilar - $o$ outro. De fato, saber semelhantizar é um dos requisitos para ser um bom poeta, segundo a concepção aristotélica. Daí a predileção pelas metáforas, pois "bem expressar-se em metáforas é bem apreender a semelhança [homoion]" (Poet. 1459a9 [p.183]): em comparação aos “nomes duplos [ou compostos] e os estrangeiros (...), o metafórico é o mais importante, pois é o único que não pode ser apreendido em função de outro nome, o que constitui índice de sua boa constituição" (Poet. 1459a5-8 [p.183]). Mas, além disso, de um modo mais geral, a discussão com Platão em relação à mimese também diz respeito às formas do semelhantizar poético. Lembremos que, ao distinguir entre relato (diegese) e imitação em sentido estrito (mimese de diálogos), narração simples, em terceira pessoa, dos atos, que mantém uma distância saudável dos personagens, e "reprodução", em primeira pessoa, "dos discursos pronunciados" (Rep. 393b, p.108), discurso indireto e discurso direto, Sócrates dirá a respeito da última: "Mas quando fala sob o nome de outrem, não diremos que torna na medida do possível a sua elocução semelhante à da personagem cujo discurso ele nos anuncia? (...) Ora, tornarmo-nos semelhantes a outrem com respeito à voz e ao aspecto não é imitar aquele ao qual nos tornamos semelhantes?" (Rep. 393c, p. 108). O verbo traduzido por J. Guinsburg como "tornar(-se) semelhante" é justamente homoioun, assemelhar - ou, como preferimos, semelhantizar. Aristóteles retomará essa distinção platônica com respeito aos diferentes posicionamentos enunciativos da mimese, caracterizando o discurso direto e o indireto como dois vetores possíveis do semelhantizar (homoioun), o outrar-se e o manter-se em si: “é possível mimetizar com os mesmos meios e com os mesmos objetos, ou pela via de narrações tornando-se outro [heteron], como faz Homero, ou permanecendo em si mesmo [auton] sem se transformar em personagens -, ou pela via do conjunto das personagens que atuam e agem mimetizando" (Poet. 1448a21-24, p. 51). Contudo, o prognóstico aristotélico é oposto ao de seu antigo mestre:

Homero é digno de ser elogiado por muitos motivos, sobretudo por ser o único dos poetas que não ignora o que deve fazer. De fato, o poeta deve falar o mínimo possível em sua própria pessoa, pois não é em função disso que se realiza a mimese. Com efeito, os outros poetas intervêm em pessoa em toda a intriga, e assim fazendo mimetizam poucas coisas e poucas vezes, enquanto Homero, após um breve 
preâmbulo, logo introduz um homem, uma mulher, ou qualquer outra personagem, nenhuma sem caracterização, ao contrário, sempre caracterizada. (Poet. 1460a5-11, p.191-193).

Isso não quer dizer, porém, que o tornar-se outro da semelhantização não esteja submetido ao controle pela verossimilhança. Desse modo, se o "terceiro ponto [no que concerne aos personagens] é a semelhança [homoion]", é preciso ter em mente que "Tanto na caracterização das personagens quanto na trama dos fatos é preciso sempre procurar o necessário ou o verossímil, de tal modo que tal personagem diga ou faça tais coisas por necessidade ou por verossimilhança e que isso se realize após aquilo também por necessidade ou por verossimilhança" (Poet. 1454a34-38, p. 129). Ou seja, para ambos - Platão e Aristóteles -, a semelhantização deve ser (co-)medida e adequada (deve se adequar...), embora de formas e por motivos distintos. ${ }^{14}$

8. A conformação da moderna noção de verossimilhança, com sua aderência ao real, e, logo, a problemática (mas ainda assim dominante) definição da arte como representação (da realidade), também tem uma origem jurídica. Mais especificamente, no debate medieval que buscou limitar o escopo das ficções jurídicas, adequando-as ao possível segundo a natureza, tal como entendida pela cristandade. Assim, Baldo (presente nos debates sobre a definição da ficção jurídica e representação medievais) irá dizer, tomando como base a Física de Aristóteles, que “a ficção imita a natureza, e por essa razão a ficção só pode ter lugar onde a verdade pode ter lugar" - mais adiante, ele especifica: "a arte imita a natureza até onde ela consegue", "a ficção imita a ideia da natureza e seu estilo (natura rationem atque stylum)" (apud KANTOROWICZ, 1961, p. 269). Tais ideias, aponta Kantorowicz, em "A soberania do artista”, adentraram as concepções artísticas da Renascença e determinaram a leitura dos preceitos da Poética aristotélica, traduzida só em 1250, incluindo a noção de verossimilhança. ${ }^{15}$ É assim que esta

\footnotetext{
${ }^{14}$ Observe-se que o antagonista de um dos diálogos platônicos caracteriza como técnica especificamente poética algo muito semelhante ao que Aristóteles descreve na passagem que estamos citando: saber adequar enunciação e enunciado, personagem e aquilo que diz. Assim, ao ser interrogado por Sócrates que "coisas" a técnica rapsódica permite conhecer, Íon responde: "Aquelas que convém, creio eu, a um homem dizer e quais convém a uma mulher, e quais a um escravo e quais a um homem livre, e quais a um comandado e quais a um comandante" (Ion 540b, p. 55). Na sua Arte poética, Horácio sintetizará essa adequação: "Se um falante destoa da própria fortuna na fala/ vão os equestres, pedestres romanos soltar gargalhada" (vv. 112-3, p. 49).

${ }^{15}$ Parte significativa do nosso argumento histórico deriva do referido artigo, que busca situar a origem de conceitos centrais do debate renascentista sobre a arte no direito medieval: "A arte deveria imitar a natureza ou ultrapassála e ir além da imitação, rumo à invenção do novo? Havia ficção envolvida, e como essa se referia à verdade? Qual era a relação entre arte e inspiração, ars e ingenium - um problema inexistente enquanto a arte era um ofício? As respostas, é claro, nunca foram uniformes, e eram contraditórias mesmo dentro da obra de um mesmo autor. Essas opiniões variadas não serão abordadas aqui (...). Por outro lado, o grupo de noções tais como ars, imitatio, natura,
} 
adquirirá uma base real, externa, a saber, a natureza e suas possibilidades. A poética é lida a partir da física cristã, e o impossível (a transformação da natureza para além de seu campo de possibilidades, ou seja, o sobrenatural) é reservado ao milagre divino. O "controle do imaginário" de que fala Luiz Costa Lima (2007) é, em seu princípio, um controle jurídico da ficção.

8. A difusão do instituto jurídico da representação também remonta à medievalidade e está associada à criação da pessoa jurídica ou moral - chamada, então, de pessoa fictícia. O contexto da sua consolidação, como aponta Yan Thomas, é patrimonial, especialmente as disputas sucessórias. Em primeiro lugar, tratava-se de coligar os dois sentidos de representação:

\begin{abstract}
Reprasentare significa, certamente, na linguagem do direito medieval, estar presente no lugar de outro, sobretudo em contexto sucessorial (...). Reprasentare pode significar igualmente, na linguagem do direito medieval, tornar presente imaginariamente, por imagem mental - o que nós sempre chamamos nesse sentido de uma representação. (THOMAS, 2005, p. 66).
\end{abstract}

Ou seja, a representação em nosso direito forjou-se cumulando "duas funções, técnica e simbólica, da representação", e também seus "dois sentidos", aquele "transitivo e ativo" (a representação "de um ausente por um presente") com outro, intransitivo "e absoluto" (THOMAS, 2005, p. 66). O objetivo de produzir essa coincidência era achar um substituto para o instituto antigo da personificação. Persona, no contexto do direito romano, designa antes um papel ou função (uma posição) do que um ator (representante), e não coincide com a individualidade corporal, pois "um mesmo indivíduo concreto pode assumir para si muitas pessoas" e "[m]uitos indivíduos, inversamente, podem ter uma só pessoa como suporte" (THOMAS, 1998, p. 98): o "direito [na antiguidade romana] opera uma verdadeira dissociação entre sujeitos e corpos, para compor "pessoas"' (THOMAS, 1998, p. 99), pois a

unidade da "pessoa" não recobre nunca primeiramente aquela de um sujeito físico ou psicológico. Ela recobre, primeiramente, originalmente, a unidade de um patrimônio (...). Em última análise, persona nomeia, no direito romano, o sujeito de direito titular de um patrimônio e os agentes (filhos, escravos), incluídos nele e que, por isso, estão habilitados a lhe representar juridicamente (...). O direito reconhecia tantas pessoas quanto eram os patrimônios, ao invés de indivíduos. Daí a possibilidade de um só sujeito conter múltiplas pessoas, ou de uma só pessoa conter muitos sujeitos. (THOMAS, 1998, p. 100).

inventio, fictio, veritas e inspiração divina é importante porque está associado com problemas que podem ser retraçados sem dificuldade aos juristas medievais" (KANTOROWICZ, 1961, p. 268). 
Os juristas medievais, informados pela antropologia e cosmologia cristãs, se viram diante da necessidade de, ao mesmo tempo, conceber uma unidade entre pessoa e "sujeito humano concreto", pessoa e indivíduo, e manter a maquinaria jurídica que permitia a unidade e transmissão do patrimônio. Eis a gênese da proliferação da representação: uma mesma pessoa (em sentido jurídico) deixa de conter múltiplos indivíduos para representá-los, um mesmo indivíduo não pode ser muitas pessoas em juízo, mas só representá-las. Assim, “Um age em nome do outro, ao invés de ser confundido com ele, e assim garante a quase presença do outro, ao invés de contê-lo. A representação assegura o princípio da unicidade das pessoas" (THOMAS, 1998, p. 100). Mesmo assim, era preciso ressaltar o caráter fictício da representação, i.e., marcar que a representação não era (só) uma função, mas uma ficção:

\begin{abstract}
É sabido que a ideia de pessoa fictícia foi formulada inicialmente por Inocêncio IV no século XIII. Mas não se prestou atenção suficiente ao meio linguístico empregado por ele. O grande papa canonista se satisfez em passar de uma palavra a outra trocando apenas uma letra: o verbo utilizado pelos textos jurídicos romanos para conferir à sucessão o papel provisório do morto, fungor ("atuar como"), é regularmente transformado por ele em fingor ("simular, fingir de"). A partir daí, os bens não ocupam mais o lugar dos mortos [na sucessão], mas age-se como se eles tivessem ocupandono. A partir daí, a função desloca-se em ficção. A partir daí, os bens (ou qualquer outro suporte) simulam a "pessoa" ao invés de assumi-la. A personalidade moral é, na Idade Média, o lugar por excelência em que os juristas opõem o "verdadeiro" ao "fictício", o "verdadeiro" ao "representativo", e em que o "representativo" se combina com o "fictício". (THOMAS, 1998, p. 101).
\end{abstract}

A ficção e a representação, combinadas ou sobrepostas, se separam do verdadeiro (da natureza). Porém, não totalmente: como vimos a partir da verossimilhança e sua leitura medieval, elas só podem ter lugar ali onde a verdade (a natureza) poderia ter lugar, mas não tem, um substituto vicário que torna, para os devidos efeitos legais, presente uma verdade/natureza ausente. Que a pessoa jurídica seja fictícia implica que ela nunca se apresente, mas sempre se re-presente, por meio de uma espécie de ciclo vicioso de pressuposição recíproca entre representante e representado que gira em torno de um vazio a que é dado o nome de ficção. Sempre ausente, ela nunca pode estar (de corpo) presente. De fato, a pessoa jurídica (antes conhecida como pessoa moral) representa as pessoas físicas que a compõem como uma entidade social ou coletiva (os sócios de uma empresa, os integrantes de um sindicato, etc.) ao mesmo tempo em que é representada por elas. A “dupla representação”, como a chama Thomas (2005, p. 69), "aquela da comunidade por sua pessoa, aquela da pessoa por seus órgãos, assembleias ou magistrados", forma "a figura de um círculo reflexivo onde os membros de uma entidade social são tanto representantes da instituição quanto representadas por ela. O mecanismo opera 
simultaneamente segundo conforme as duas vozes, ativa ou passiva". Dito de outro modo: a pessoa jurídica só representa as físicas sob a condição e na medida em que é representado por elas, não comparecendo em juízo, ou aparecendo em qualquer ato legal, a não ser por intermédio de seus representantes (que ela representa), mas que não se confundem nem se transformam nela. A presença de uma se funda na (e opera pela) ausência dos outros - mas também de si mesma. Autonomizada pela ficção jurídica, a representação torna o vicário (o verossímil) o único presente, deixando de ser um fazer novamente (ou de forma diferida) presente (representar), e passando a ser o mecanismo que se faz presente a si mesmo pela remissão às presenças que o fundariam, mas que, sendo ficcionais, só podem estar ausentes.

9. De novo, uma comparação com os povos contra o Estado pode ser reveladora, afinal, neles nos deparamos com um contínuo entre imitação e transformação, não discretizado pela representação, ficção e/ou verossimilhança. "Em Maxakali”, aponta Roberto Romero, "imitar é 'yīkox yãy hãa', algo como 'virar [tornar-se] a boca' de alguém [e] 'yãy hã ' é justamente transformar, virar". De modo semelhante, diz Beatriz Matos, "os Matsés não falam em termos de 'imitação', mas sim em transformar ou 'virar' alguma coisa, mesmo quando é uma brincadeira e estamos imitando um animal, por exemplo. Usam um sufixo verbal '-ua', como em 'matsesaua', virar gente."16 Não se trata, porém, meramente de uma questão linguística, mas conceitual e pragmática. Assim, para os Aikewara, como elabora Orlando Calheiros (2015), os diferentes povos e mesmo as diferentes espécies animais se caracterizam não por uma diferença de "natureza", mas de caminhos, caminhos que não são determinados por uma essência, mas por um crescimento ou movimento conjunto: dependem da comensalidade, dos hábitos (culturais e alimentares), das práticas e desejos, etc. Agir como um porco, por exemplo, está sempre na iminência de fazer com que o sujeito tome o caminho dos porcos e se torne um. Os exemplos poderiam se multiplicar. Em todos eles, porém, o contato entre imitador e imitado, não triangulado pela noção e instituição da representação ou da ficção, sempre pode se tornar contágio: abrigar um outro em si pode sempre implicar outrar-se, o artifício pode sempre se "naturalizar". 17

\footnotetext{
${ }^{16}$ Ambas as informações me foram transmitidas por comunicação pessoal. Agradeço a Beatriz e ao Roberto por terem prontamente me respondido a consulta.

${ }^{17}$ Seria interessante pensar como o contínuo entre imitação e transformação se manifesta formalmente, i.e., no modo mesmo de contar histórias ("imitar" os relatos míticos) ou cantar a fala alheia ("imitar" o que dizem os espíritos). Em relação ao xamanismo marubo (numa análise extensiva a outros povos e regiões), Pedro Cesarino (2006, 2011, 2015) apontou como a estrutura paralelística e formulaica dos cantos possibilitam a variação tendencialmente infinita dentro do que pareceria a repetição de um padrão fixo. De outro ângulo, Lúcia Sá, em "Histórias sem fim: perspectivismo e forma narrativa na literatura indígena da Amazônia", argumentou, a respeito
} 
10. Tomemos de forma mais detida um exemplo muito conhecido, A queda do céu, cuja forma enunciativa ou narrativa, diga-se de passagem, é a mesma do Grande sertão: veredas (chamada pela crítica "diálogo virtual”, "monólogo-diálogo", etc.), pela qual só temos acesso à fala de um, mas através dele sabemos da presença de um outro: a não ser nos paratextos, só um, só Davi Kopenawa, fala, sem, porém, que se trate de um monólogo, pois ele não cessa de se referir a Bruce Albert, seu interlocutor, de colocar palavras na sua boca, de responder às suas perguntas, etc. ${ }^{18}$ Um leitor atento à teoria estética mais em geral, e à teoria literária em específico, não pode deixar de se inquietar, no sentido positivo, com a onipresença do verbo "imitar" e do substantivo "imitação", utilizados para designar desde a atividade xamânica (o canto dos xamãs

de mitos ameríndios, que "Em vez de resolução, o que move essas narrativas é a transformação, entendida não como uma mudança definitiva de um estado a outro, mas como um processo contínuo e permanente. Daí a importância da etiologia que explica como as pessoas (pessoas animais, humanas, espíritos), plantas e coisas adquiriram as características atuais" (SÁ, 2020, p. 176). Sá se contrapõe aqui a certa tradição que insistia em ver os "epílogos etiológicos" como apêndices desconectados (ou desconectáveis) do que seria o cerne do relato, servindo mais para marcar o fim de um episódio (ou de uma parte dele): ao contrário, eles servem para marcar que a transformação é não só o próprio conteúdo dos relatos, assim como a sua própria forma - na medida em que o motivo etiológico, enquanto dispositivo isomórfico, funciona formalmente como passagem de um segmento a outro, de um episódio a outro, ou mesmo, de um mito a outro, constituem um mecanismo formal que permite acoplar (bricolagem do pensamento selvagem [LÉVI-STRAUSS, 1989]) uma estória na outra, trans-formando uma em outra, mantendo a estrutura "imitativa" aberta a adições, numa verdadeira "história sem fim" que não cessa de se transformar (e transformar a história) - histórica e estoricamente (cf. NODARI, 2017). "Supõe-se então que o estado atual é sempre precário, pois carrega dentro de si a possibilidade de novas mudanças. Alimentos e venenos ganham outro significado metafórico: caçados, pescados ou cultivados a partir de sementes ou de enxertos, os alimentos e os venenos são então processados ou cozidos para serem absorvidos e convertidos pelo corpo em energia, antes de serem expulsos como resíduos que irão alimentar outros alimentos. Eles são, neste sentido, os significantes últimos dos vários processos transformativos que conectam as pessoas (pessoas humanas, animais e espirituais) umas às outras e aos ambientes que as cercam. Longe de serem acessórios casuais ou sem importância, os epílogos etiológicos de nossas histórias [dos três mitos que Sá analisa] (que explicam a aquisição de um determinado alimento ou veneno) destacam a lógica transformadora e a coerência formal das narrativas indígenas amazônicas." (SÁ, 2020,p. 176).

${ }^{18}$ Trata-se do que sugeri chamar de tradicção (cf. NODARI, 2018), noção que retomarei adiante, mas que nesse contexto adquire outras ressonâncias. Afinal, A queda do céu gira muito em torno de dois regimes discursivos completamente diferentes, dois agenciamentos da língua, das línguas, que diferem radicalmente entre si, a palavra xamânica e a palavra escrita, dois caminhos ou trilhas, apresentando uma perspectiva da fala xamânica sobre a escrita dos brancos, mas sendo, por outro lado, escrito, ou transcrito, e traduzido por um branco, Bruce Albert. Trata-se de uma tensão que dá forma ao livro, que é formalizada no livro, que se torna a sua forma: uma transformação da escrita a partir da perspectiva da fala xamânica sobre ela. A transcrição, a tradução para a escrita, se dá, assim, pelo prisma da fala xamânica, ou seja, se Davi imita as palavras de Omama, dos xapiri, etc., se a sua palavra não é própria, se a sua dicção está atravessada por essas palavras de outrem, também está pelas palavras de Albert; por sua vez, Bruce, ao imitar as palavras de Kopenawa (e as de Omama, dos xapiri, e a sua própria) nas "peles de imagem", no papel, ao tornar as suas palavras palavras de outrem, embutidas na fala de Davi, imita não só as palavras, mas o próprio agenciamento discursivo/enunciativo da fala xamânica. Além disso, enquanto fruto de décadas de conversas entre Kopenawa e Albert, o livro não apresenta uma disposição sequencial desses diálogos, nem a marcação de quando cada fala se deu - mas, antes, uma montagem e seleção que encavalga os diversos tempos em que as conversas se deram: ou seja, a configuração temporal do livro é também dada pela concepção da fala xamânica. Por fim, cabe notar que esses dois regimes discursivo-enunciativos comportam duas ecologias: Kopenawa insiste que nós brancos desenhamos sobre folhas de árvores mortas, ao passo que os cantos dos xapiri se originam das árvores (vivas) amoa hi, cujas folhas são coletadas por espíritos dos pássaros. 
sendo uma imitação de segundo grau: imitação do canto dos espíritos, que, por sua vez, é imitação dos cantos da árvore amoa hi) até os costumes dos yanomami mais jovens em sua tentativa de papagaiar os brancos. ${ }^{19}$ A primeira ocorrência de "imitar" se dá já na segunda linha do livro (se excetuamos os paratextos introdutórios), no endereçamento de Kopenawa ("Palavras dadas"), e em referência a Albert: "Faz muito tempo, você veio vier entre nós e falava como um fantasma. Aos poucos, você foi aprendendo a imitar minha língua e a rir conosco." (KOPENAWA; ALBERT, 2015, p. 63). Tal aprendizado e imitação da língua é logo ligado à aquisição de uma intimidade, de um parentesco, de um rir junto, o que é reforçado na página seguinte, em que o rir já é um comer, a comensalidade, forma de aproximar, de acercar, de criar um caminho conjunto: “Se lhe perguntarem: 'Como você aprendeu essas coisas?', você responderá: 'Morei muito tempo nas casas dos Yanomami, comendo sua comida. Foi assim que, aos poucos, sua língua pegou em mim. Então, eles me confiaram suas palavras, porque lhes dói o fato de os brancos serem tão ignorantes a seu respeito"” (KOPENAWA; ALBERT, 2015, p. 64). Há um processo aí em jogo, da imitação ao aparentamento, da língua imitada a uma língua que pegou, da imitação ao (quase-)parentesco, do aprendizado ao (quase-)tornar-se.

11. A relação entre xamã e xapiri, no relato de Kopenawa, também se dá toda sob o signo da “imitação". ${ }^{20}$ A princípio, é o xamã que "morre", se torna espírito ou imagem, e assim pode

\footnotetext{
${ }^{19}$ Bruce Albert não apresenta, em nenhuma nota ou paratexto, qual(is) termo(s) yanomami traduz por "imitar" ou "imitação". O Diccionario enciclopédico de la lengua yãnomãmi, de Lizot (2004), apresenta ao menos um verbo que tem como uma de suas acepções mais diretas a de "imitar": owë-, que tem dois sentidos: o primeiro é aproximar-se de, acercar-se de, num sentido físico; o segundo, imitar, parecer-se a algo, agir como alguém, atuar como alguém, parodiar, e medir (tomar uma coisa como parâmetro da outra, contar com os dedos). Ou seja, a imitação como uma aproximação, um movimento, um caminho em direção a outro, se quisermos. Contudo, como a imitação se apresenta, no discurso de Davi, em um contínuo com a transformação, é bem provável que outras formas ou construções sejam mobilizadas. Por exemplo, a verbalização de substantivos, como em napeai, imitar os brancos ou, diríamos, embrancar (napë: branco/inimigo/forasteiro + -i: verbalizador); ou em watupaтиu, "fazer como urubu" (Kopenawa e Albert, 2015, p. 674) (watupa: urubu + -тии ou -mou, partícula cuja função varia), nome de um ritual de guerra, e харіrimии, termo que indica uma "sessão de xamanismo", mas que significa mais literalmente "agir como espírito" (KOPENAWA; ALBERT, 2015, p. 621) (xapiri: espírito + -mии). O sufixo prou, embora indique mais diretamente "virar", como em napëprou, "virar branco", não deixa de participar desse contínuo no qual, por um lado, como mostrou Kelly (2016), o tornar-se nunca é total, formando um gradiente tendencialmente infinito, e, por outro, a imitação nunca é totalmente isenta do risco de transformação.

${ }^{20}$ Seria interessante explorar a importância do japim (e dos pássaros em geral) para a ecologia discursiva xamânica da imitação. Lembremos que um dos primeiros espíritos a colher cantos da amoa hi é o do japim ayokora, um pássaro conhecido pela capacidade de imitar os cantos de muitos outros: "o japim", diz Albert (2018, s. p.), "é particularmente notável, tanto nos termos de sua estética e de sua visibilidade, quanto de seu excepcional talento como poliglota. Essa ave dos extremos da floresta, que vive em grandes colônias, é realmente capaz de imitar mais de quarenta espécies de pássaros, mamíferos, anfíbios e insetos ou mesmo os sons vindos das casas humanas (gritos, choros, latidos) interpondo suas imitações dentro de seus próprios cantos e chamados. Trata-se, portanto, de uma espécie de cantor emblemático, um meta-cantor capaz de reproduzir a maioria das músicas de animais da floresta. Sem dúvidas, é por esta razão que o espírito xapiri dessa ave possui uma importância tão peculiar no xamanismo Yanomami: é o único espírito que permite aos xamãs regurgitar à vista de todos as plantas de feitiçaria
} 
imitá-las: “Apenas os xamãs são capazes de contemplar os xapiri, pois, tornados outros com a yakoana, podem também vê-los com olhos de espíritos" (KOPENAWA; ALBERT, 2015, p. 118); é nos espelhos, prossegue, "que depositam nossa imagem quando nos fazem xamãs". Ou seja, imitar aqui envolve tornar-se outro, tornar-se imagem. Todavia, a imitação parece estabelecer uma via de mão dupla no eixo da transformação, pois implica também um processo de aparentamento por meio do qual o xamã vai se tornando pai dos xapiri, que passam a morar em uma casa localizada em seu (do xamã) peito, e depois no céu: “O espelho de dança deles está instalado na minha casa de espíritos e sempre respondo a seus cantos enquanto bebo o pó de yakoana. Às vezes, são eles que vêm me visitar por conta própria no tempo do sonho. Então, faço-os dançar em silêncio.” (KOPENAWA; ALBERT, 2015, p. 230). Estabelece-se, aí, uma relação de parentesco, que envolve comensalidade, mas na qual o pai não só deve alimentar seus filhos, mas também imitá-los (numa inversão da lógica esperada na relação entre pais e filhos, em que aqueles são o exemplo a ser imitado por estes):

Os xapiri de um xamã o chamam de 'pai' porque permanecem junto dele, que os alimenta de pó de yãkoana. Não o chamam de nenhum outro modo. Se o pai não os incomodar com o cheiro das folhas de mel que enfeitam as braçadeiras das mulheres, se imitar seus cantos com acerto e se beber yãkoana frequentemente para fazê-los dançar, os espíritos, satisfeitos, ficam com ele (...). Se, ao contrário, ficam com fome

\footnotetext{
e os objetos malignos que eles extraem do corpo dos doentes. O mimetismo sonoro do japim lhe confere esse privilégio xamânico que ecoa o mimetismo ontológico dos xamãs, cujo trabalho consiste justamente em se identificar com as 'imagens' dos ancestrais animais dos primeiros tempos que eles 'chamam', 'fazem descer', e 'fazem dançar' na forma de espíritos auxiliares, adotando sua subjetividade e sua expressão vocal”. Trata-se, deve frisar, de uma figura disseminada para além dos yanomami. Assim, entre os Marubo, "As mulheres-espírito sabiá (mawa), japiim (txana), papagaio (vawa), isá e shatxĩ tapõ (duas espécies de uirapuru) são as que fazem o desenho [kene] dentro do peito dos romeya [pajés] para que ele possa então imitar (naroa) todas as falas de outrem." (CESARINO, 2011, p. 82). Além disso, veja-se, a título ilustrativo, o excerto dessa entrada sobre o japiim no capítulo "Bichos de pena" (de autoria de Margarete K. Mendes, Moisés Piyãko, Maira Smith, Edilene Coffaci de Lima e Terri Valle de Aquino) da Enciclopédia da floresta - O Alto Juruá: práticas e conhecimento das populações (devo a Marcos Matos a indicação dessa referência): "O japiim (japinim, xexéu) é um pássaro respeitado e admirado por todos os habitantes da floresta, por sua capacidade de imitar o canto ou a fala de qualquer outro animal, pelos elaborados ninhos que tece e pelo seu 'modo de vida' (...). Para os Ashaninka, os japiins têm um comportamento muito parecido com o deles próprio: 'Moram bem pertinho e vivem bem, sem brigar'. Acreditam os seringueiros que 'se der chá de miolo do japinim para criança pequena (antes de começar a falar), ela fica com uma inteligência medonha [privilegiada], fala muito!' (...). O canto do macho possui muitas variações e é capaz de imitar o canto de outros pássaros, tais como o do tucano (todas as espécies), da saracura, do papagaio, da arara, do bem-te-vi, do pinheiro, do cancão, do jacu, do corrupião, da cigana, do gavião, do uirapuru, do sabiá e até latido de cachorro. Dizem os seringueiros que o japinim arremeda todo tipo de bicho, até choro de menino, mas não arremeda o bico-de-brasa, porque, segundo eles, esse pássaro bebeu o sangue do pai do japinim, por isso tem o bico encarnado; o japinim ficou com medo de arremedá-lo, porque, se o fizesse, este enfiaria o bico na bunda do japinim. // Para os Kaxinawá, o japiim só não arremeda o uirapuru porque, quando tentou fazê-lo, 'levou uma pisa dele'. Os Kaxinawá dão o nome desse pássaro (txana) aos principais cantadores de seus rituais. Para aprender mais rapidamente e não esquecer todas as canções desses rituais, faz-se o seguinte: mata-se o chefe mais cantador de um bando de japiim, tiram-se o couro e as penas junto com a cabeça e as pernas e seca-se ao sol ou perto do fogo, guardando-os em seguida para os dias de festa" (CUNHA; ALMEIDA, 2002, p. 523-524).
} 
e irritados, se sentem maltratados e acabam fugindo de volta para o lugar de onde vieram, para nunca mais voltar. (KOPENAWA; ALBERT, 2015, p. 126).

Contudo, de novo, a imitação parece ser recíproca, com os xapiri "imitando" seus pais, se tornando parecidos com eles: ao menos, isso parece sugerido quando Kopenawa fala sobre os xapiri de xamãs falecidos, os xapiri órfãos: "se parecem muito com seus finados pais. Assim, quando vêm dançar em forma de fantasma, vemos através deles os antigos xamãs que os tinham, e sua lembrança volta a nós com muita saudade" (KOPENAWA; ALBERT, 2015, p. 127). É como se o contínuo entre imitação e transformação envolvesse uma formação de parentesco, numa via de mão dupla. ${ }^{21}$ Nesse sentido, a série de analogias que Davi apresenta para falar da imitação (por exemplo, quando ele afirma que os espíritos dos pássaros colhem os cantos da árvore amoa hi com um objeto invisível parecido com gravador de branco) parecem ser mais equivocações do que equivalências, mais traduções que sinonímias. Por isso, talvez pudéssemos penar a imitação em jogo como um aparentar(-se) a outro, fórmula que busca manter ao mesmo tempo o parentesco e a transformação, jogando com o duplo sentido de aparentar (parecer e virar parente), bem como com a direção desse movimento, tanto ir em direção ao outro quanto o revés, em suma, uma aproximação, um acercar-se do outro: 1) Parecer o outro (imitar); 2) Tornar-se parente do outro; 3) O outro tornar-se parente seu (nos dois casos, tornarse outro); 4) Aparecer ao outro; 5) Fazer aparecer o outro.

12. A imitação como aparentar(-se) a outro não pode ser reduzida à representação no sentido que a descrevemos acima. Isso se torna nítido em uma passagem em que Kopenawa invoca, no mesmo gesto que torciona, esse (nosso) vocabulário:

Todos os seres da floresta possuem uma imagem utupë. São essas imagens que os xamãs chamam e fazem descer. São elas que, ao se tornarem xapiri, executam suas danças de apresentação para eles. São elas o verdadeiro centro, o verdadeiro interior dos animais que caçamos. São essas imagens os animais de caça de verdade, não aqueles que comemos! São como fotografias destes. Mas só os xamãs podem vê-las. A gente comum não consegue. Em suas palavras, os brancos diriam que os animais

\footnotetext{
${ }^{21}$ Outro caso emblemático é o marubo, no qual a aquisição de conhecimento e a aprendizagem de cantos de seres de outros planos cósmicos envolve o aparentamento dos duplos dos xamãs (duplos que não são essências interiores das pessoas - "O duplo é quase idêntico à pessoa: é ela própria, mas o rosto é diferente" [CESARINO, 2011, p. 69] -, mas parentes: irmãos mais velhos) com aqueles, com os quais casam, ou entre os quais descobrem seus pais, tios, etc.: "A poética xamanística constrói seu sentido em um interminável comentário sobre o parentesco sociocósmico, nos diálogos e mensagens que atravessam um campo indefinido de relações." (CESARINO, 2011, p. 129). Assim, por exemplo, "Pássaros são, a rigor, o exemplo prototípico da vida-espírito por seu ágil olhar e deslocamento, por sua loquacidade e frequente hábito gregário. Quando inalado, o pó de rapé costuma deixar um rastro de fina fumaça que se transforma em uma multidão de espíritos-pássaro, de semblante e pensamentos similares aos do [xamã] cheirador, de quem são parentes. Alhures, ajudarão seu 'fazedor' (shovimaya) a falar e pensar." (CESARINO, 2011, p. 178).
} 
da floresta são seus representantes (...). Essas imagens de animais tornados xapiri são muito bonitas mesmo quando fazem suas danças de apresentação para nós, como os convidados no começo de uma festa reahu. Os animais da floresta, em comparação com elas, são feios. Existem, sem mais. Não fazem senão imitar suas imagens. (KOPENAWA; ALBERT, 2015, p. 116).

Essa curta passagem, por si só, é capaz de curto-circuitar por completo o que entendemos por imagem: enquanto fotografias dos animais, as imagens vêm temporalmente antes daquilo de que são imagens, como se fossem reproduções a priori; estranhas fotografias pois que, além disso, não se assemelham em aparência aos fotografados ("Os animais da floresta, em comparação com elas, são feios”); e, por fim, invisíveis, ou quase, já que os xamãs podem vê-la com a condição de que antes estes sejam vistos por ela (no relato de Davi, são os xapiri que o observam e depois passam a visitá-lo no sonho para que ele os veja). Mas, além disso, também o que concebemos como representação se coloca em xeque. Assim, se, por um lado, os xapiri são "como fotografias" dos animais que comemos, ou seja, sua representação (no "sentido estético"), por outro, os animais atuais são ditos representantes dos xapiri (em uma acepção político-institucional: em nota, Albert menciona que a 'palavra 'representante', em português, faz parte do vocabulário político corrente dos líderes indígenas" (KOPENAWA; ALBERT, 2015, p. 621). Mas mesmo essa aparente distinção entre os dois sentidos da representação parece não ser tão clara, remetendo, antes que a uma diferença, a uma espécie de reciprocidade representacional, uma representação de via de mão dupla, uma imitação enquanto aparentar(-se) a outro. Pois se Kopenawa insiste que os xapiri não se parecem com os animais atuais, isso não o exime de lançar mão, para descrever os atributos e armas dos xapiri, de analogias com os seus representantes animais: "Outros xapiri lutam com lanças, como o espírito da arraia yamara aka - o ferrão desse peixe é perigoso, não?”, etc. (KOPENAWA; ALBERT, 2015, p. 129). Quem representa quem?

13. Poderíamos arriscar dizer que estamos diante de representações em dois campos ou regimes de visibilidade distintos: os animais que comemos representam os xapiri no campo do que é visível aos "homens comuns", enquanto os xapiri representam (são como que fotografias d)os animais que comemos no campo daquilo que só é visível aos xamãs e espíritos. Mas esses dois planos diferentes (no limite, dois mundos diferentes, com naturezas diferentes) não cessam de se sobrepor (talvez seja isso que a representação recíproca que podemos extrair da fala de Davi indique), de se encontrar, entrecruzar, e transformar um ao outro, e a atividade xamânica ou ritual consiste em produzir, controlar, influenciar ou intermediar tais encontros. Já deve ter 
restado claro que a imitação em jogo é inseparável de uma performatividade, que o aparentamento a/de outro em questão não pode se dissociar de uma produção de efeitos. $\mathrm{O}$ próprio Kopenawa ressalta isso em uma comparação entre a imitação dos xapiri e aquela das palavras bíblicas, ou seja, entre duas formas de comunicação e interação com outro plano: "Quando se imitam as palavras de Teosi não se vê nada: nem os seres maléficos, nem o mal das plantas de feitiçaria, nem os espíritos da epidemia. Teosi deve ser preguiçoso, já que não faz esforço algum para nos curar, nem quando estamos agonizando. Morremos à toa, sem ele nem se preocupar. Ao contrário, os xapiri demonstram muito empenho em nos vingar." (KOPENAWA; ALBERT, 2015, p. 278). Distintamente da imitação passiva e sem efeitos visíveis (e também sem visualidade efetiva), imitar, quando se imita os xapiri, implica conseguir ver, fazer aparecer, ou seja, imaginar no sentido forte, ver/produzir imagens, e estabelecer relações com elas, aproximar-se delas, torná-las próximas para que elas ajam.

14. No vocabulário da teoria literária dos mundos possíveis, se diria que o xamã realiza uma "viagem transmundo" ("transworld travel" [DOLEŽEL, 2000, p. xi]) $)^{22}$ - e, de fato, salvo engano, Jaider Esbell, em sua fala no Seminário Metamorfoses de Macunaíma (na UNICAMP, 2019), argumentou que a arte e o xamanismo indígenas produziam viagens transmundos. Como se sabe, a associação entre poesia e magia é um lugar comum, e uma de suas formulações conceituais mais acabadas talvez seja de Cortázar. Em "Para uma poética", o poeta é definido como um "fazedor de intercâmbios ontológicos" ao "cumprir a forma mágica do princípio da identidade e ser outra coisa" (CORTÁZAR, 2008, p. 95). Trata-se, vale deixar claro, do contrário do princípio lógico da identidade, ou melhor, trata-se da assunção de um princípio da contradição, do terceiro incluído cuja manifestação mais concreta na linguagem é a metáfora: o poeta e o mago "aceitam a imagem absoluta: A é B (ou C, ou B e C): aceitam a identificação que faz saltar em pedaços o princípio da identidade" (CORTÁZAR, 2008, p. 90) - "um salto no ser, uma irrupção em outro ser, em outra forma do ser" (CORTÁZAR, 2008, p. 95), em uma “[e]xploração daquilo-que-não-é-o-homem” (CORTÁZAR, 2008, p. 96), de “qualidades ontológicas que não são as do homem”, “[p]orque 'o outro' é, na verdade, aquilo que lhe pode dar graus do ser alheios à específica condição humana” (CORTÁZAR, 2008, p. 98). Cortázar,

\footnotetext{
${ }^{22}$ Tomamos a obra de Doležel como referência por marcar a posição mais dominante, embora haja uma série de nuances no debate, entre as quais vale destacar a interessante postulação de Pavel (1986) de uma "ontologia dual" operando nas obras literárias. Cf. também, mas em um sentido mais elaborado e em outro contexto, mais amplo, de discussão, o que Catren (2016) fala das viagens transumwélticas, mais próximas do nosso horizonte.
} 
assim, define a atividade mágico-poética não como uma fusão (“duas coisas que são uma”), mas, a partir de Lévy-Bruhl, como uma "participação", ademais, recíproca, "entre os seres que participam uns dos outros! A essência da participação consiste, precisamente, em apagar toda dualidade; apesar do princípio de contradição, o sujeito é ao mesmo tempo ele próprio e o ser do qual participa" (LÉVY-BRUHL apud CORTÁZAR, 2008, p. 90). A diferença entre o mago e o poeta consistiria que este buscaria a magia em outro plano, o das essências. Contudo, aqui, Cortázar não leva devidamente em consideração que essa diferença de planos implica uma descontinuidade quanto à eficácia, ligada tanto à institucionalização da poesia quanto ao processo moderno de psicologização da experiência artística, a sua institucionalização no interior do sujeito, como um evento cognitivo ou mental, reduzida ao imaginário. Tal processo transforma radicalmente o estatuto ontológico da experiência poética e dos diferentes planos ou mundos ou naturezas envolvidas nos "intercâmbios". Retomemos o jargão da teoria literária dos mundos possíveis, em que os mundos ficcionais (aqueles dos textos literários) são descritos como independentes, autônomos ou mesmo soberanos, i.e., totalmente separados do nosso, de que se diferenciam negativamente, contudo, por serem "incompletos" (DOLEŽEL, 2000, p. 22) - sua existência só vai até o que o texto diz a seu respeito. Ou seja, são mundos não só possíveis, como plausíveis, talvez até mesmo prováveis, com suas regras próprias, em suma, mundos verossímeis (no sentido de que são verossimilmente um mundo, sem sê-lo), mas não verdadeiros como o nosso, pois não possuem o mesmo status ontológico. ${ }^{23}$ Eles não podem entrar em contato com o nosso e transformá-lo do mesmo modo (com o mesmo tipo de eficácia) que os outros planos e mundos xamânicos, pois, por um lado, a sua autonomia impede, e, por outro, a incompletude revela que não se tratam de mundos de fato: a independência é um atributo puramente lógico, não efetivo, e, ao fim e ao cabo, tais mundos dependem de um substrato deste mundo, estão dentro do nosso mundo (e nossas “mentes”), são ficções (representações) criadas em nosso mundo, de que são derivados. "Ao compor um texto oral ou escrito", diz Doležel (2000, p. 23),

o autor cria um mundo ficcional que não estava disponível antes desse ato. A poiesis textual, como toda atividade humana, acontece no mundo atual; contudo, ela constrói reinos ficcionais cujas propriedades, estruturas, e modos de existência são, a princípio, independente das propriedades, estruturas e modo existencial da atualidade (...). Graças à forca ilocucionária particular do texto literário, possíveis se tornam existentes ficcionais, mundos possíveis se tornam objetos semióticos.

\footnotetext{
${ }^{23}$ Ou seja, o debate da teoria literária dos mundos possíveis parece se dar sob o signo do que Meinong (2008) chamou de "preconceito a favor do atual".
} 
Mais adiante, ao especificar como funciona tal poiesis, a partir da narração tradicional em terceira pessoa, "modo de autenticação" mais acabado, criador de mundos por excelência, dotado de plena força ilocucionária, ele afirma: "É precisamente a palavra divina criadora de mundo que provê o modelo para a narrativa autorizativa e sua força performativa" (DOLEŽEL, 2000, p. 149). Não só a "autenticação" e a "autorização", como a própria soberania do artista enquanto criador ex nihilo à imagem de Deus remete mais uma vez ao vocabulário jurídicoinstitucional. Afinal, como apontou Kantorowicz (1961), a figura do artista como criador a partir do nada (concepção alheia ao mundo greco-romano) também remonta à teologia políticojurídica medieval, mais especificamente à caracterização do papa como Cristo ou Deus vicário capaz de, como aquele que representa, fazer algo (transformar o mundo) a partir do nada (mais especificamente, pela palavra, daí a equiparação desse poder com o de legislar). Tal atributo da arte divina teria depois se estendido ao Imperador, e, mais tarde, aos artistas. No ponto de chegada dessa visão, coligado à institucionalização da arte (que retira a eficácia da poiesis poética), a saber, a concepção romântica do gênio criador, secularizada na vulgata cognitivista segundo a qual os mundos ficcionais são criações mentais (ou do cérebro), nesse ponto de chegada, está o preceito atual de que a poesia vem de dentro (do interior do sujeito, o que implica também do próprio mundo) e vai para dentro (o interior do outro sujeito, o leitor, também desse mundo). A figura de uma força externa, ou melhor, de um sujeito externo, que habita outro plano, fora do nosso, mas que se intersecciona com ele (as musas, a inspiração divina) é interiorizada psicologicamente. Nada mais distante das artes verbais xamânicas ou rituais, nas quais o contato com o fora não é só seu objetivo, mas também sua origem, nas quais é do exterior que provêm os cantos (e, por vezes, como entre os Yanomami, do exterior do exterior: os xapiri, mas antes deles, a árvore dos cantos). Os Khĩsêtjê levam isso a um ponto extremo: "todos os cantos", diz Seeger (2015, p. 115), "eram provenientes de fora da sociedade khĩsêtjê", seja de seres transformados nos tempos míticos, outros povos indígenas ou mesmo dos brancos (caso em que são cantados na própria língua estrangeira). O caso-limite é o dos cantos provenientes de homens sem espírito (katwâni), "pessoas sem 'dentro"" (people with no 'inside'), como define Marcela Coelho de Souza (2018, p. 195, 196), daqueles que, devido à ação de algum feiticeiro, tiveram seu espírito refugiado no mundo/aldeia de outra espécie animal, "seu dentro revirado para fora" (their inside [katwâni] turned outside), vivendo em dois mundos distintos ao mesmo tempo. Comenta Seeger (2015, p. 117): “Quando a pessoa doente descobria onde estava sua alma - depois que, nas palavras de Ropndo, ela 'se via' -, sua 
metamorfose em um ser dual, vivendo na aldeia khĩsêtjê e na aldeia animal, se completaria". De lá, da aldeia animal, o espírito do homem sem espírito manda para cá, para a aldeia humana, para o homem sem espírito, os cantos: "Os cantos novos eram ensinados por especialistas que passaram por uma metamorfose parcial, assumindo uma espécie de marginalidade permanente (...). Entre os Khĩsêtjê, onde havia metamorfose, havia canto" (SEEGER, 2015, p. 117). Não só a imitação leva à metamorfose (como nos cantos de invocação), como também a metamorfose (do “cantor”) leva à imitação (dos cantos). ${ }^{24}$

15. Nesse ponto, um esclarecimento metodológico se mostra necessário. O percurso histórico e comparativo que realizamos sobre a experiência literária visa apontar que a ontologia da literatura é, sempre, situada (i.e., variável e contingente). Por ontologia, entendemos não só a série discursivo-institucional que define o que a literatura é, conferindo-lhe seu estatuto e posição, mas também o conjunto de práticas (a escrita, a leitura, seus efeitos existenciais e na subjetividade, etc.) que a constituem efetivamente enquanto uma experiência. É evidente que os dois níveis se interseccionam mas não coincidem, de modo que é possível que a experiência efetiva seja ou possa ser diferente daquilo que as instituições e teorias definem (impõem) performativamente. De fato, em outras oportunidades (especialmente em NODARI, 2015), tentei apontar como a experiência literária pode ser repensada em termos (ontológicos) outros que os normalmente utilizados, lançando mão do vocabulário da antropologia contemporânea - mais especificamente a teoria do perspectivismo de Eduardo Viveiros de Castro. Aqui, porém, aprofundando esse exercício, optei por um contraste entre os lugares (e efeitos) ontológicopolíticos que ocupam, por um lado, a literatura no Ocidente moderno e, por outro, as artes verbais (xamânico-rituais) nos povos ameríndios (contraste generalista, escusado dizer, e que parte do corte clastreano entre sociedades com e contra o Estado). O objetivo, contudo, não é parar aí. Trata-se, agora, de tentar ver como "nossas” categorias linguístico-literárias (metáfora, contexto, enunciação, referência, representação) são deslocadas a partir da(s) experiência(s) poética(s) indígena(s), com o intuito não só de entender a diferença dos dois regimes, mas de retroalimentar nosso arsenal teórico de compreensão da literatura. ${ }^{25} \mathrm{Em}$ "Cosmological deixis

\footnotetext{
${ }^{24}$ De novo, trata-se de algo disseminado entre povos ameríndios: a atividade xamânica requer transformações físico-espirituais, requer tornar-se outro, outrar-se.

${ }^{25}$ Retomando a imagem de Lévi-Strauss, se a arte é um parque natural do pensamento selvagem no pensamento domesticado, isso quer dizer que o seu modus operandi é aparentado àquele dos mundos cujo pensamento não foi totalmente colonizado pelo Ocidente, embora não seja igual, afinal, o estatuto/lugar (institucional e discursivo) conferido à floresta "selvagem" (natureza protegida pelo parque) afeta o que ela é. Dito de outro modo: a nossa experiência artística pode ser caracterizada como perspectivista, o que transparece na sua comparação com mundos
} 
and amerindian perspectivism", Viveiros de Castro (1998, p. 476) advertia que "As almas ameríndias, sejam elas humanas ou animais, são assim categorias indexicais, dêiticos cosmológicos cuja análise demanda menos uma psicologia animista ou uma ontologia substancialista que uma teoria do signo ou uma pragmática perspectivista". Como se sabe, a teoria de Benveniste (os dêiticos, em especial as posições enunciativas "eu", "tu”, "ele"; as noções de contexto e referência pensadas a partir da enunciação) foi o solo linguístico das formulações da pragmática do perspectivismo ameríndio. O que tentaremos, a seguir, é aprofundar do ponto de vista conceitual tal pragmática, vendo como, no seio das poéticas indígenas, seus próprios termos podem ser eles mesmos perspectivados.

16. Ao abordar a Festa do Rato khĩsêtjê, Seeger salienta "um aspecto linguístico bem interessante" dos cantos ali entoados:

[os cantos] se referiam a si mesmos, a ação acompanhava o discurso ou o canto a respeito de si própria. No caso dos cantos-chamado, o cantor que cantava "o rato pula e canta" estava ele mesmo pulando e cantando; o cantor que cantava sobre o corte de sua máscara teria (ou teria tido) sua máscara cortada. (...) Qual é o motivo dessa redundância entre discurso e ação? Por que falar sobre algo, se você está fazendo esse algo? Por que fazer referência ao sujeito no mesmo instante em que a ação do sujeito é visível? Nos cantos-chamado, talvez seja porque a identidade do sujeito que está cantando é ela mesma ambígua. Na noite final da Festa do Rato, os cantores passariam por uma metamorfose na qual se tornariam um tipo de ser que era tanto gente como rato. O "eu" dos cantos seria, portanto, ambíguo: era tanto humano como rato. Em várias das letras dos cantos-chamado citados, o canto concerne a um rato, mas os verbos estão na primeira pessoa. Na linha $\mathrm{n}^{\circ}$. 16 , por exemplo: "o rato preto pula e canta; eu pulo e canto". O sujeito é rato e gente a um só tempo; na metamorfose da noite final, de fato, o rato e a pessoa são um ente só. As letras dos cantos em uníssono apresentavam uma ambiguidade semelhante. (...). No canto, a ambiguidade está no sujeito: é um homem ou um rato cantando? É um homem cantando sobre um animal, ou é um animal cantando pela boca de um homem? Não há resposta simples. O que a autorreferência das letras faz, entretanto, é trazer os dois participantes para a

indígenas, mas, nesse contraste fica evidente também que se trata de um perspectivismo de outra ordem, de um perspectivismo outro (assim como o perspectivismo de Leibniz, Nietzsche e Ortega y Gasset é outro em relação ao formulado por Viveiros de Castro, embora se aparentem). Ou seja, no encontro com o outro (com um mundo outro), "nossas" categorias não podem fazer a viagem de volta incólumes. Isso em dois sentidos: 1) o primeiro, mais trivial, é que elas não podem voltar do jeito que eram antes do encontro; 2) mas, além disso, elas também não podem voltar do jeito que passaram a ser depois do encontro, pois há ainda a cena do re-encontro, do retorno - o deslocamento e transformação por que passaram não podem ser aplicadas sem mais à nossa experiência literária, sob o risco de anular a diferença que está na origem de sua modificação e realinhamento. O deslocamento deve ser deslocado novamente na volta. O movimento, assim, não é apenas um contraste entre o eu e o outro, ou uma transformação do eu no outro, mas o da (re)constitutição do eu como outro do outro. Aqui, não faremos o movimento de retorno, o que já esboçamos, de algum modo, em outro lugar (NODARI, 2019). Ali, procurei repensar as posições enunciativas na experiência literária e as consequências ontológicas disso, sem, porém, explicitar (por falta de escopo, espaço e mesmo clareza de minha parte) que na base dessa reproposição estava justamente o movimento de deslocamento (de ida) a partir do contraste com as poéticas xamânicas ameríndias. Trazer à luz isso que ali permaneceu oculto é um dos objetivos das páginas que se seguem. 
performance: tanto os executantes humanos como os animais estão presentes nas letras. (SEEGER, 2015, p. 105-106).

Se reformulamos as perguntas de Seeger do ponto de vista da representação, um curtocircuito semelhante (embora diferente) àquele das formulações de Kopenawa vem à tona: é um homem representando (imitando) o rato ou o rato representando (imitando) um homem? É claro que em um sentido, é "só" um homem "representando" um rato, desde que aceitamos a recíproca: a de que é claro que, em outro sentido, é "só" o rato representando um homem - ou mesmo o rato representando um homem representando um rato... Aqui, a noção de representação talvez seja insuficiente, porque não se trata simplesmente de representar outro plano, mundo ou natureza, mas também de presentificá-lo ou apresentá-lo no mesmo gesto em que reciprocamente se apresenta ou presentifica esse plano ao outro. Por isso, diferentemente do modelo ocidental canônico da representação, de matriz jurídica, a representação na Festa do Rato não consiste em tornar presente o ausente, e tampouco se caracteriza como uma ficção, uma mera presença vicária verossímil do representado. Se ainda podemos nos manter no vocabulário da representação, talvez fosse mais adequado dizer que o que está em jogo é uma transpresentação, i.e., um tornar mutuamente presentes dois planos, mundos ou naturezas, e ao mesmo tempo tornar presente seu encontro e atravessamento. Pois aqui, os participantes do ritual (assim como o pajé em eventos xamânicos) situam-se em mais de um plano ou mundo ao mesmo tempo (ocupando, como veremos, mais de uma posição enunciativa), de modo que a autorreferência de que fala Seeger é imediatamente também uma alter-referência, pois referirse a si mesmo é referir-se ao outro: nessa representação recíproca, o representante (e representado) de um mundo e o representante (e representado) de outro - o homem é representante do rato (representado) ao mesmo tempo que o rato é representante do homem (representado) - estão ambos presentes, de corpo presente, ocupando um mesmo "corpo" na cena ritual, cujo estatuto ontológico é atravessado por ambos os vetores, e por isso mesmo instável ou variável (verdadeira "metamorfose em ato", como diria Haroldo de Campos [2004, p. 59] sobre Macuncôzo de "Meu tio o Iauaretê"), devendo, portanto, ser contida. Afinal, há sempre o risco do não retorno, de modo que ao fim da cerimônia, "os homens [que] se tornam seres que também são ratos, mas ratos em seu papel social de cantores, dançarinos e mestres do milho" devem "morrer", ter suas máscaras removidas e serem banhados, pois "há sempre a possibilidade de os homens não retornarem a sua forma humana.” (SEEGER, 2015, p. 107). 
17. O que estamos sugerindo chamar de transpresentação pode assumir diferentes formas. Assim, no xamanismo marubo, um duplo do pajé romeya viaja a outros mundos, saindo de seu corpo-maloca, o qual, então, recebe um outro, um (ou mais) espírito(s), que cantará(ão). Ou seja, que um se re(a)presente aqui implica que o outro se re(a)presente lá (cf. CESARINO, 2011). A mesma cena - a cena outra da transpresentação - se dá, de forma distinta, em duas cenas. Uma duplicação ainda mais espelhada (ou simétrica) pode ser vista entre os Matsés, em um "grande ritual coletivo de iniciação masculina, em que espíritos eram evocados para levarem consigo meninos e rapazes, e fazê-los crescer. O termo mais usado pelos Matses para se referirem a esses espíritos é cuëdënquido, que significa "o que canta" (cuëdën = cantar; quid= nominalizador, agente)" (MATOS, 2014, p. 147). "Uma das características mais notáveis da cerimônia”, aponta Beatriz Matos (2014, p. 160),

\begin{abstract}
é que ela se desdobrava em uma dupla sequência de acontecimentos. Os homens que chegaram a participar desses rituais contam que não só os espíritos visitavam a maloca matses, mas também os matses visitavam a maloca dos espíritos. Essa troca de visitas se dava simultaneamente, enquanto os cuëdënquido cantavam com as mulheres matses, os homens matses cantavam com as mulheres cuëdënquido.
\end{abstract}

Além disso, a transpresentação envolve também uma dimensão temporal, uma travessia de presentes de temporalidades de ordem distintas. "Por todas as terras baixas da América do Sul, até onde sabemos”, diz Seeger (2015, p. 35), “a música é empregada para representar e criar uma transcendência de tempo e substância: passado e presente são ligados, e humanos e inumanos se comunicam e comungam. Até certo ponto, o tempo e a potencialidade do mito se restabelecem no presente pelo som das flautas, dos chocalhos e da voz". De fato, o ritual (como também o xamanismo), e a Festa do Rato é um exemplo disso, torna presente o mito, não no sentido simples de um retorno ao tempo mítico em si, mas no de atualizar a virtualidade da espaço-temporalidade mítica que permeia o cosmos e que possibilita o encontro de mundos ou planos, sem, porém, que o tempo presente (histórico) deixe de ter lugar. Afinal, se o mito é o tempo da diferença intensiva e de sua passagem à diferença extensiva (entre espécies, naturezas, etc.) que caracteriza a história e o tempo presente ${ }^{26}$, o ritual (e o xamanismo) torna intensivas

\footnotetext{
26 “Ali [na mitologia indígena], muito longe de qualquer indiferenciação originária entre humanos e não-humanos - ou índios e brancos etc. -, o que se vê é uma diferença infinita, mas interna a cada personagem ou agente (ao contrário das diferenças finitas e externas que codificam o mundo atual). Donde o regime de metamorfose, ou multiplicidade qualitativa, próprio do mito: a questão de saber se o jaguar mítico, digamos, é um bloco de afecções humanas em figura de jaguar ou um bloco de afecções felinas em figura de humano é rigorosamente indecidível, pois a metamorfose mítica é um acontecimento ou um devir (uma superposição intensiva de estados), não um "processo" de "mudança" (uma transposição extensiva de estados). A linha geral traçada pelo discurso mítico descreve a laminação desses fluxos pré-cosmológicos de indiscernibilidade ao caírem no processo cosmológico:
} 
as diferenças extensivas, sem que estas, porém, deixem de estar presentes ${ }^{27}$ : assim, na Festa do Rato, o rito concentra em um só corpo homem e rato, mas de forma instável, pois se o corpo do participante reúne intensivamente a diferença extensiva entre homem e rato, é só como instante de passagem (desse modo, "mítica") de uma espécie a outra: o homem está mascarado de rato, imitando o rato, mas, sem as devidas precauções ao fim da Festa, tornará-se um, pois o corpo que dá lugar à diferença intensiva se extensivará, e pode dar lugar, no final, tanto a um corpo de homem quanto a um corpo de rato.

18. Um dos pressupostos mais importantes e conhecidos postulados pelo perspectivismo é o multinaturalismo: ao contrário do multiculturalismo, que (re)conhece uma só natureza (mundo), e muitas culturas ("línguas", diríamos, formas de vê-lo), a ontologia dos povos ameríndios conhece muitas naturezas (mundos), mas uma só cultura ("língua", forma de vê-los). ${ }^{28}$ Daí a "equivocação": o que nós integrantes da espécie humana vemos e chamamos de "sangue" é cerveja para o jaguar, o que vemos e chamamos de rio é, para os peixes, sua aldeia ou floresta (cf. VIVEIROS DE CASTRO, 2004). Não se trata, porém, de sinonímia: não é que seres humanos e onças chamem a mesma coisa (substância) por nomes diferentes (como no mononaturalismo ocidental); é a coisa mesma nomeada que é outra conforme a natureza de referência. Na equivocação, é o mesmo nome que se refere a coisas diferentes, de acordo com o mundo em que se está: a própria coisa é diferente de acordo com quem a nomeia (a partir da posição-mundo de referência). Do ponto de vista da linguística, isso implica uma espécie de deitificação tendencial de toda a "língua" ("única" para todas as naturezas), pois, assim como os pronomes pessoais e os demais shifters (embreantes), em especial advérbios (aqui, agora, ontem, lá, etc.), mas também as formas verbais, no multinaturalismo, os "signos nominais" são como que (tendem a ser) pronominais, pois aquilo a que se referem (a natureza mesma daquilo a que se referem) varia de acordo com o mundo a que pertence o sujeito da enunciação. Todavia, não é que, no perspectivismo, os signos nominais sejam simplesmente pronominais, variando de acordo com o locutor individual (ou o contexto em seu sentido usual), pois não estamos diante de um subjetivismo generalizado. Embora a forte presença de marcadores

\footnotetext{
doravante, o aspecto humano e o aspecto jaguar do jaguar (e do humano) funcionarão alternadamente como fundo e forma potenciais um para o outro. A transparência absoluta se bifurca, a partir daí, em uma invisibilidade (a alma) e uma opacidade (o corpo) relativas - relativas porque reversíveis, já que o fundo virtual é indestrutível ou inesgotável” (VIVEIROS DE CASTRO, 2002, p. 419).

${ }^{27}$ Devo a Andressa Lewandowski, a quem agradeço, essa formulação.

${ }^{28}$ Isso coloca um problema tradutório, ou melhor, possibilita repensar mesmo o que é uma tradução: o que se traduz num encontro trans-mundo se a língua é a "mesma”? Cf. Nodari (2020b).
} 
evidenciais/experienciais em muitas línguas indígenas (um caso emblemático é o Yudjá, no qual se diz "choveu para mim" ${ }^{29}$ ) possa dar essa impressão de uma indexação total da linguagem ao sujeito individual de referência, ela aponta, antes, para uma incerteza de fundo sobre qual mundo está vigendo na interlocução, i.e., se o interlocutor pertence ao mesmo mundo objetivo que o locutor (trata-se de uma incerteza ou indeterminação constitutiva, pois a própria pessoa ameríndia é múltipla, se constituindo por distintos processos de aparentamento de e com outros planos, naturezas e mundos). Vejamos mais de perto a distinção que Benveniste (1995, p. 278) faz entre os dêiticos (tomando como paradigma o "eu") e os signos nominais:

\begin{abstract}
O enunciado que contém eu pertence a esse nível ou tipo de linguagem a que Charles Morris chama pragmático (...). Cada instância de emprego de um nome refere-se a uma noção constante e "objetiva", apta a permanecer virtual ou a atualizar-se num objeto singular, e que permanece sempre idêntica na representação que desperta. No entanto, as instâncias de emprego de $e u$ não constituem uma classe de referência, uma vez que não há "objeto" definível como eu ao qual se possam remeter identicamente essas instâncias. Cada $e u$ tem a sua referência própria e corresponde cada vez a um ser único, proposto como tal (...). Eu só pode definir-se em termos de "locução", não em termos de objetos, como um signo nominal. $E u$ significa "a pessoa que enuncia a presente instância de discurso que contém "eu".
\end{abstract}

Não se poderia dizer, sem mais, que, no perspectivismo, os signos nominais não constituam uma "noção constante e 'objetiva", e que suas instâncias de emprego não formem uma "classe de referência", ou mesmo que essa noção não "permanece sempre idêntica na representação que desperta" - dentro de cada mundo, "as instâncias de emprego" de um signo nominal “remete[m] identicamente” a um “"objeto' definível”. A deitificação dos signos nominais, a sua pronominalização, só ocorre quando se dá um encontro trans-mundo, em que naufraga uma das condições da enunciação na teoria de Benveniste, a referencialidade, obrigando-nos a repensar a cena enunciativa de outro modo, a especular sobre uma outra cena: "na enunciação, a língua se acha empregada para a expressão de uma certa relação com o mundo.

\footnotetext{
29 "Em meu trabalho de campo, uma das primeiras coisas a chamar-me a atenção foi a marca indelével, mas muito misteriosa, da noção de ponto de vista. Certas frases, ditas para mim em português, como 'isso é bonito para mim', 'bicho virou onça para ele', 'apareceu caça para nós quando estávamos fazendo a canoa', pareciam remeter exclusivamente à estrutura gramatical de uma língua que eu não dominava, mas que transparecia no português dos Juruna. Depois que comecei a arranhar algumas frases, as construções que ensejavam tais traduções nunca deixaram de soar estranhas; dentre as práticas juruna mais difíceis de assimilar eu as destacaria, em primeiro lugar e sem hesitação. Amãna ube wï — não é fácil dizer isso sem se desconcertar, desagradavelmente ou não. Sentiame dizendo 'choveu para mim', e não 'choveu onde eu estava'. Essa maneira de relacionar à pessoa até mesmo os acontecimentos mais independentes e alheios à nossa presença deixa sua marca na cosmologia juruna, mas nem presumo que todas as categorias gramaticais tenham o mesmo papel em uma cultura, nem acredito que exista a mais remota possibilidade de algum de nós se colocar na pele de um Juruna para captar o sentido que assumiria a vida humana em uma situação em que, para nós, de repente, se tornaria aceitável, ou mesmo perfeitamente justo, dizer: Chove para mim." (LIMA, 1996, p. 30).
} 
A condição mesma dessa mobilização e dessa apropriação da língua é, para o locutor, a necessidade de referir pelo discurso, e, para o outro, a possibilidade de co-referir identicamente, no consenso pragmático que faz de cada locutor um co-locutor. A referência é parte integrante da enunciação.” (BENVENISTE, 2006, p. 84). Nos contatos entre mundos, sobrenaturais por excelência (em que há mais de uma natureza em jogo) ${ }^{30}$, a correferência não é idêntica, mas essencialmente equívoca. "Cerveja" nomeia uma bebida embriagante tanto para os humanos quanto para o jaguar: há um "consenso pragmático", pois a noção de cerveja "permanece sempre idêntica na representação que desperta", e a "relação com o mundo" expressa na enunciação é a mesma - o mundo é que é outro. Na cena enunciativa trans-mundo, a referência se bifurca, pois a língua única é enunciada a partir de (pelo menos) dois mundos (naturezas) diferentes. É isso que as artes verbais xamânico-rituais formalizam linguisticamente (poieticamente), de modo a performativamente mobilizar ou produzir os encontros entre mundos por meio da correferência a mais de uma natureza. Daí sua linguagem "multireferencial”, como Townsley (1993, p. 453) a caracteriza a partir dos Yaminawa, pois, diz Cesarino (2011, p. 138) a respeito do xamanismo de outro povo Pano, "os eventos [do ritual xamânico] (...) se dão simultaneamente aqui $e$ na outra referência”, em mais de um plano ao mesmo tempo. A "ubiquidade" da situação trans-mundo faz com que seja frequente nessas práticas verbais o uso de metáforas, já que nelas trata-se "de bifurcar ou disparatar um enunciado em dois referentes possíveis" (CESARINO, 2011, p. 156). ${ }^{31}$ Poder-se-ia dizer que a multirreferencialidade ou bifurcação referencial constitui uma verdadeira transreferencialidade,

\footnotetext{
${ }^{30}$ Em outra ocasião, tentaremos esmiuçar teoricamente (novamente tendo em vista possíveis revisões de categorias da teoria literária) o topos específico do "encontro sobrenatural na mata", tal como exposto por Viveiros de Castro. ${ }^{31}$ Metáforas, segundo um pajé e professor marubo, são "nomes [de determinadas coisas] usados para transformar" (CESARINO, 2015, p. 76): nomeiam o processo de formação (mítica) de algo, logo, tornam pensável e acessível a sua transformação. Por sua vez, os xamãs yaminawa, segundo Townsley (1993, p. 460), se referem às metáforas dos cantos koshuiti como "linguagem retorcida": "Com meu koshuiti eu quero ver - cantando, eu examino cuidadosamente as coisas - a linguagem retorcida me deixa perto mas não perto demais - com as palavras cotidianas eu colidiria com as coisas - com as torcidas eu as contorno - posso vê-las claramente". Isso porque o conhecimento xamânico diz respeito aos yoshi, "espírito ou essência animada" de tudo o que existe, caracterizados por uma extrema ambiguidade, ao mesmo tempo aparentados aos seres de que são espíritos mas distintos deles (como os xapiri na descrição de Kopenawa): "Você nunca conhece realmente os yoshi - eles são algo que você reconhece e ao mesmo tempo eles são diferentes - como quando eu vejo Jaguar - há algo nele como um jaguar, mas também talvez algo como um homem também - e ele muda... (...) [Os yoshi] são sempre 'como... e não como', 'o mesmo que...' mas diferente." (TOWNSLEY, 1993, p. 453). Por isso, continua Townsley (1993, p. 464), a “[m]etáfora aqui não é a linguagem imprópria (figurada), mas a única nomeação própria possível”, pois quando dois mundos se sobrepõem, quando tudo é ao mesmo tempo próximo mas diferente, o impróprio (o bifurcado, retorcido) é o mais próprio (direto e imediato): "Em linguagem retorcida, ele [o xamã] enumera todas as características do (...) [objeto a ser conhecido ou transformado], tanto empíricas quanto míticas, fazendo da sua visão a mais acurada e completa possível. De novo, seu objetivo é visionar (...) [o objeto] de modo tão direto, imediato e total que ele possa conhecer e apreendê-lo de alguma maneira absoluta".
} 
pois consiste em se referir a mais de um mundo ao mesmo tempo, de uma referência atravessar a outra, de transferir uma referência de um plano a outro e, ainda, referir-se a esse atravessamento mesmo, na medida em que o xamanismo não implica apenas um trânsito entre dimensões cosmológicas distintas, mas também a sua sobreposição ou atravessamento, que visa produzir uma transformação nesse mundo por meio de uma transposição, em que algo que estava lá vem para cá ou vice-versa (curar alguém expulsando um agente agressor de outro plano, transferir propriedades de outra espécie, atraindo um espírito de outra natureza, ganhar nomes ou cantos de alhures, etc.) - um atravessamento sem fusão que transforma reciprocamente os mundos que se sobrepõem. Assim, retomando o exemplo khĩsêtjê do canto de invocação do caititu: trata-se ali de "imitar" o porco, suas qualidades, para transpô-las, de sua natureza “animal” à humana, fazê-la passar de um mundo a outro, transformando-o.

19. A partir de um contexto etnográfico distante dos que temos invocado aqui, mas repleto de ressonâncias com eles, Roy Wagner aproximou o ritual justamente à metáfora:

a justaposição de campos causais ou experienciais aparentemente não relacionados em uma metáfora "esconde" a analogia, ou fio de sentido, que os conecta, ao passo que a analogia tem o potencial de resolver a discrepância, assim como a solução de um enigma ilumina uma proposição que de outro modo seria sem sentido. A alusão a dois "campos" não relacionados, geralmente realizada pela referência a um deles no contexto do outro, representa o "potencial" da relação, e é isso que a conexão metafórica, ou analogia, controla, alinhando campos separados (...), estruturando sua interação de modo a prover um incremento de potência para alguma atividade. Tal alinhamento é capaz de ter consequências para ambos os campos envolvidos, e em alguns casos, a estruturação de cada área acarreta um resultado que é útil aos homens. (WAGNER, 1972, p. 58-59, 68-69). ${ }^{32}$

Referir-se a um campo (ou plano ou mundo) no "contexto do outro" constitui uma boa definição da bifurcação referencial, bem como aos efeitos visados quando do uso ritual ou xamânico da transreferencialidade: produzir relações entre mundos distintos visando um

\footnotetext{
${ }^{32}$ Citemos, de passagem e como comparação sem comentário, o que Ortega y Gasset (1991, p. 38) diz da metáfora, por ele caracterizada como "bomba atômica mental": "duas realidades, ao serem identificadas na metáfora, chocam-se uma com a outra, se anulam reciprocamente, se neutralizam, se desmaterializam". O teatro, "metamorfose, prodigiosa transfiguração" (ORTEGA Y GASSET, 1991, p. 36), seria, nesse sentido, uma "metáfora corporificada", porque não apresenta o ser como tal ou o ser tal como é, mas o "ser como": "Pois bem, o mesmo acontece no teatro, que é o 'como se' e a metáfora corporificada - portanto, uma realidade ambivalente que consiste em duas realidades - a do ator e a da personagem do drama que mutuamente se negam. É preciso que o ator deixe durante um momento de ser o homem real que conhecemos e é preciso também que Hamlet não seja efetivamente o homem real que foi. É mister que nem um nem outro sejam reais e que incessantemente se estejam desrealizando, neutralizando para que só fique o irreal como tal, o imaginário, a pura fantasmagoria" (ORTEGA Y GASSET, 1991, p. 39). Observe-se, ainda, como termo comparativo à caracterização dos yoshi (são como X, mas diferentes de X) e o uso de metáforas para descrevê-los, o comentário de Max Müller sobre os Vedas retomado por Ortega: neles, "a metáfora se expressa (...) dizendo que uma coisa é como outra, mas precisamente por meio da negação"; assim, por ex., "fortis non leo, é forte, mas não é um leão." (ORTEGA Y GASSET, 1991, p. 39).
} 
"resultado que é útil aos homens". Mas, além disso, evoca também o que está em jogo no gesto de citar: na citação, o que é citado é, diz Benjamin (2006, p. 518), "arrancado de seu contexto" e referido (ou transferido ou sobreposto) a outro (sem que perca totalmente a referência ao contexto original). E, de fato, as citações de falas alheias, do que o xamã ou o seu duplo ouve dizerem em outro mundo, muitas vezes na forma de um embutimento citacional em cascata (A disse que B disse C disse X), são recorrentes nas artes verbais xamânicas ameríndias, e estão relacionadas à situação enunciativa trans-mundo. "O canto xamanístico é uma canção de canções, um discurso de discursos, é polilógico" (VIVEIROS DE CASTRO, 1986, p. 548), fazendo com que a "complexidade dos embutimentos e multiplicidade de posições enunciativas, isto é, a posição dos emissários e destinatários no campo perspectivo do evento xamanístico" (CESARINO, 2011, p. 137) lhe confira "uma dimensão multiposicional”: assim, no xamanismo marubo, "um visitante-espírito cita o que disse o duplo do romeya [pajé], que diz o que determinados espíritos falaram sobre si, sobre o próprio romeya ou sobre outras pessoas desta referência" (CESARINO, 2011, p. 137). As citações, desse modo, também conferem (ou se dão a partir da) multirreferencialidade às poéticas do xamanismo, e a partir do emblemático caso araweté, Guilherme Orlandini Heurich (2015, p. 150-151) propôs vê-las como uma maneira de sobrepor (e atravessar) mundos, especialmente quando mobilizam de forma explícita a deiticidade da linguagem (que, como vimos, se dissemina nessas situações):

\begin{abstract}
Aquilo que o xamã diz não apenas torna essas relações [entre homens e seres espirituais e entre esses] visíveis como também aponta para os diferentes mundos embutidos nas citações. A questão é se essas formas de citação implicam em uma descontextualização da fala alheia ou em outra coisa. Parece-me que podemos pensálas como ações que sobrepõe diversos contextos (ou mundos) em uma mesma fala. Quando essa fala questiona a humanidade dos envolvidos e usa palavras cujo referente não é fixo - inimigo, tatu, gente, etc. -, creio que a definição de um "contexto referencial" da citação fica comprometida. Ou seja, se "gente" é algo que aponta para referentes (mundos) diferentes de acordo com o sujeito que fala, talvez não seja possível estabelecer um contexto de referência e, portanto, talvez não haja contexto para ser "descontextualizado". Por isso, penso que a noção de contexto talvez possa ser substituída pela de mundo e a ação de citação possa ser pensada como uma sobreposição de mundos. O resultado disso é uma imagem do signo que, talvez, propõe uma noção diferente de contexto.
\end{abstract}

Estamos aqui no coração do problema: não há contexto de referência fixo porque não há texto de referência fixo, isto é, porque o que está sendo dito (citado) refere-se a mais de um mundo por ser enunciado (dito $e$ citado) simultaneamente em mais de um mundo. O contexto, nesse contexto, talvez só possa ser entendido como o do próprio encontro sobrenatural transmundo, não coincidindo plenamente nem com aquele de onde provém a citação (o dos espíritos) 
nem com aquele em que é citado (o humano), mas com a co-incidência que se dá na citação mesma, e daí sua transreferencialidade. A multiposicionalidade deriva da transposicionalidade do xamã, pela trans-posição que ele ocupa e efetua pela palavra ou canto: a espaçotemporalidade do contato entre planos heterogêneos e que não constitui um plano como os demais. A melhor aproximação talvez se dê com imagens da física ou da ficção científica: se “o chocalho do xamã é”, na bela definição de Viveiros de Castro (2008, p. 45), "um acelerador de partículas", então talvez o evento que ele produza seja algo como um buraco de minhoca ou uma dobra espaço-temporal (a espaço-temporalidade mítica em que as diferenças extensivas tendem a se intensivar novamente), onde se passa a cena xamânica ou ritual, o seu contexto.

20. Periodicamente, os Aikewara realizam o puruhai karuwara, ritual que visa como que purgar a ameaça de sua devoração pelos espíritos canibais. Responsável por desbravar o caminho dos vivos, a fuga dos Aikewara dos mortos (Karuwara), o cantor aikewara (se'engara'e), de tempos em tempos, tem um sonho premonitório, no qual vê um deles na iminência de atacar os seus. Ora, o que ele descobre é que o Karuwara do sonho não é ninguém senão ele mesmo. Na medida em que todo homem adulto após morrer se torna um desses espíritos canibais, o cantor, que morre diariamente na atividade xamânica, já está morto, já é também karuwara, mesmo estando vivo. Terceira margem, cantor dos vivos e cantor dos mortos, o se'engara'e, segundo Orlando Calheiros (2014, p. 295), "não apenas faz as vezes de limiar entre os mundos, mas atua como uma porta entre eles": "Sua voz se duplica, suas palavras portanto, vem aos pares, tanto em sua língua natal, quanto na língua do inimigo; seus cantos se desdobram em dois, em uma música para os viventes, e outra para os karuwara" (CALHEIROS, 2014, p. 273). E é desse eu-mesmoenquanto-morto que o cantor recebe os cantos que são entoados na cerimônia de purgação. $O$ segmento de um deles é significativo para entender a (trans-)posição do se'engara'e, bem como, de um modo mais geral, a enunciação xamânico-ritual:

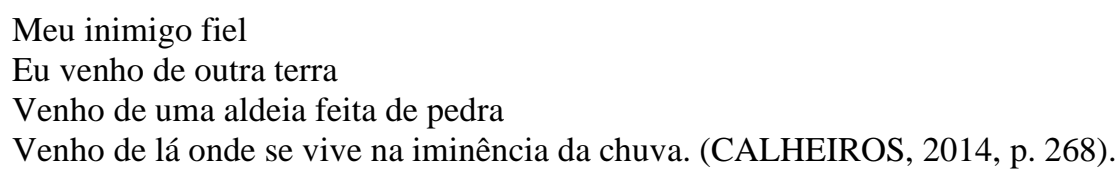

Aqui, quem canta é o cantor aikewara, mas as palavras (citadas) são "dele mesmo" enquanto espírito canibal (karuwara), se dirigindo a "ele mesmo" enquanto vivo, numa situação enunciativa de espelhamento máximo, pois poder-se-ia dizer que o contrário é o que ocorre: é o cantor aikewara vivo que dirige esse canto a si mesmo enquanto morto. Se a forma por 
excelência na literatura da multiplicidade enunciativa é o discurso indireto livre (caracterizado por Banfield [1982] como discurso sem sujeito, o que poderia ser repensado como o discurso do sujeito zero, o "múltiplo universal” [STERZI, 2019, p. 249]), aqui, o mesmo efeito é atingido por uma espécie de discurso sobre- ou hiper-direto, isto é, a sobreposição e atravessamento de dois discursos diretos que, por meio de um mesmo corpo, são emitidos por e referem-se a dois sujeitos distintos ao mesmo tempo $e$ a esta co-incidência.

21. Se a equivocidade contamina a referenciação na cena enunciativa do encontro entre mundos, ela afeta também os dêiticos em si, a começar pelo "eu”. Afinal, eles também operam por meio de uma referência: se $e u$ é o "indivíduo que enuncia a presente instância de discurso que contém a instância linguística $e u$ ", então temos "uma dupla instância conjugada: instância de $e u$ como referente, e instância de discurso contendo eu, como referido." (BENVENISTE, 1995, p. 279). Mas a quem se refere "eu" numa enunciação trans-mundo? As línguas e a escrita oferecem aparatos formais para diferenciar quem está dizendo o quê, delimitar quem está dizendo "eu", separar o citante do citado: os distintos modos - verbos, sufixos, etc. - de demarcar o sujeito da enunciação, seja no discurso direto, seja no indireto, o uso de aspas, etc., em suma, os meios que fazem da "heterogeneidade constitutiva" da enunciação uma "heterogeneidade mostrada" (AUTHIER-REVUZ, 1990), ou seja, que separam, no discurso, o outro (eu) do eu - e daí o potencial crítico do projeto benjaminiano de "desenvolver ao máximo a arte de citar sem aspas." (BENJAMIN, 2006, p. 500). Contudo, nem sempre toda essa parafernália é suficiente. O exemplo aikewara de equivocação do "eu” está longe de ser único. Já vimos o caso da Festa do Rato khĩsêtjê, sobre o qual se poderia arriscar dizer que os homens quando, imitando o rato, pulam e cantam dizendo "eu pulo e canto", estão citando o rato - toda imitação é (ou se aproxima a) uma citação. E, como vimos, se autorreferência é uma alter-referência (e também uma transreferência, uma referência a esse atravessamento referencial), isso se deve ao fato de que mesmo que os homens estejam citando o rato, eles estão também dizendo eles mesmos o que o rato está dizendo - no fundo, toda citação comporta ou deriva dessa ambiguidade possível. Há, ainda, outros exemplos, tão ou mais evidentes. Retornemos aos Araweté, agora ao embutimento citacional do canto xamanístico Mãi marakã que envolve

Três posições: um morto, os Mãi, o xamã, em um sistema onde o morto é o principal enunciador, transmitindo citacionalmente ao xamã o que disseram os Mãi. Mas o que os Mãi disseram é quase sempre algo dirigido ao morto, ou ao xamã ou a si mesmos sobre o morto ou o xamã. Assim, a forma típica de uma frase é uma construção dialógica complexa: o xamã canta algo dito pelos Mãi, citado pelo morto, referente a 
ele (xamã), por exemplo... Quem fala, assim, são os três, Mãi, morto, xamã, um dentro do outro. (VIVEIROS DE CASTRO, 1986, p. 549).

No chamado Canto da Castanheira, coletado e traduzido por Viveiros de Castro, temos, ocupando essas três posições principais (embora outros também falem), o xamã, Kãñĩpaye-ro, que cita o que sua filha morta, Kãñĩpaye, diz que os deuses canibais, os Mãi, disseram em outro plano sobre o nosso. ${ }^{33}$ Especialmente instrutivo, para nossos propósitos é o décimo-terceiro verso, em que o pajé cita a morta citando os deuses: “Acenda meu charuto jogado fora, disse o deus'." (VIVEIROS DE CASTRO, 1986, p. 555). Comenta Viveiros de Castro:

\begin{abstract}
O verso 13 traz a menina transmitindo ao pai o que o deus pediu a ele, xamã - que acendesse seu charuto. Esse é um gesto de cordialidade, sugerindo que o xamã deve oferecer seu charuto ao Mãi (o "meu charuto" é na verdade o tabaco do xamã). ora, nessa mesma ocasião o charuto de Kãñĩpaye-ro havia-se apagado, e sua esposa teve que acendê-lo. O verso evidencia assim uma espécie de curto-circuito ou construção em abismo: o pedido dos deuses ao xamã é um pedido do xamã à esposa por intermédio da filha, etc. (VIVEIROS DE CASTRO, 1986, p. 556).
\end{abstract}

Tais curto-circuitos não são bugs dêiticos ou "falhas na Matrix", mas uma espécie de “interferência cosmológica” (VIVEIROS DE CASTRO, 1986, p. 562) - e creio que Viveiros de Castro estivesse aqui jogando com a difundida imagem amazônica do xamã como um rádio: a interferência cosmológica é uma espécie de interferência da radiofrequência, em que dois sinais de origem distinta são captados ao mesmo tempo, com a peculiaridade de que a mensagem que emitem é a mesma. Índice da transubjetividade do encontro entre mundos, tais curtos-circuitos não estão restritos ao Mãi marakã, mas aparecem em artes verbais, seja de outros povos ameríndios ${ }^{34}$, seja de outro tipo dos próprios Araweté. Desse modo, em outro canto ritual araweté, entoado por guerreiros que mataram um inimigo, o embutimento citacional multiposicional (A disse que $\mathrm{B}$ disse que $\mathrm{C}$ disse $\mathrm{X}$ ) pode se curto-circuitar: o matador (A) canta o que o seu inimigo morto (B) diz, mas o outro (C) que este cita (na fala $\mathrm{X}$ ) pode muito bem ser o matador ele mesmo (A) e o que ele disse (X): A disse que B disse que C/A disse X, numa situação enunciativa em que A ao mesmo tempo (se) cita e diz, diz ele mesmo e diz através do outro. Em uma "canção atribuída a Yakati-ro, um homem araweté falecido em 1976, que lhe

\footnotetext{
${ }^{33}$ A transreferencialidade revela, assim, "uma função do canto xamanístico, que é o de comentar, pela boca do morto, eventos atuais." (VIVEIROS DE CASTRO, 1986, p. 566). Dessa maneira, no Canto da Castanheira, a "menina diz ao pai que os deuses disseram que eles 'não comeram a coisa' - isto é, não foram chamados ainda a comer jaboti pelos humanos. À época do canto iniciavam-se os preparativos para as caçadas coletivas de jaboti, mas nenhuma refeição fora oferecida aos Maĩ. O canto de Kãñ̃ipaye-ro dirige assim uma mensagem geral à aldeia." (VIVEIROS DE CASTRO, 1986, p. 555). Como os diferentes planos ou naturezas não cessam de se sobrepor, independente da vontade de humana, cabe aos pajés, especialistas nesse trânsito, garantir ou negociar (por vezes belicamente) os termos em que tal sobre- ou transposição se dá.

${ }^{34}$ Cf., por exemplo, o "curto-circuito polifônico" de um canto marubo em Cesarino (2011, p. 142-143).
} 
foi ensinada por uma vítima do povo Parakanã”, aquele cita este citando, nos versos finais, àquele: "Eis meu prisioneiro, / no pátio do grande pássaro"” (o "pátio do grande pássaro" "é uma metáfora macabra para a clareira aberta pelos urubus na floresta, em torno do inimigo morto - entenda-se, do cadáver do homem parakanã que é o sujeito da enunciação deste canto.” (VIVEIROS DE CASTRO, 2002, p. 276). "Yakati-ro, o matador-cantor, fala de si mesmo, falando as palavras de sua vítima, as quais são uma citação do que ele estaria dizendo: o matador 'repete' portanto suas próprias palavras. Uma espécie de ecolalia enunciativa, ou um processo de reverberação: um inimigo morto (...) cita seu próprio matador (...) pela boca desta último.” (VIVEIROS DE CASTRO, 2002, p. 277). Nesses - e em tantos outros - casos, quebra-se a ordem do discurso, da enunciação, da representação, pela qual deve-se preferir o discurso indireto ao direto de outro (Platão), ou então pela qual o discurso direto de outro deve ser distinto do próprio, ou seja, verossímil (Aristóteles), plenamente mostrado ou demarcado como sendo de outro, em que as posições do discurso estão delimitadas, em que o outro só fala vicária e ficcionalmente, estando sempre ausente, jamais de corpo presente, só representado. Neles, também a multiposicionalidade (A, B, C), no ato da enunciação trans-mundo (o dizer $\mathrm{X}$ ) comporta tendencialmente e como condição de possibilidade a transposicionalidade, o atravessamento posicional, a posição da travessia de posições. A transposição ocupada pelo xamã ou participante do ritual (ou de qualquer um que esteja numa situação de encontro entre mundos) pode ser visualizada na Festa do Rato, em que há, a princípio, duas posições enunciativas (dois "eus") de mundos distintos que falam por uma mesma fala, boca ou corpo: a posição-homem (A) e a posição-rato (B); mas, além deles, há a posição do "eu" ocupado ou ocupante, a fala, boca ou corpo que diz "eu" e que, ao dizê-lo, oscila entre as duas posições anteriores, as atravessa, a corposição, corpo-posição ou posição corpo (C), que é a do homem imitando, citando, se transformando no ou se aparentando ao rato e vice-versa, uma terceira posição que faz da autorreferência uma alter-referência e se refere ao cruzamento referencial, representante $e$ representando, representação corporificada, dentro $e$ fora da cena, a própria encenação, pois o agenciador discursivo é também agente do discurso agenciado. A multiplicidade das posições das situações enunciativas trans-mundo, embora possam muitas vezes serem demarcadas, deriva da possibilidade de seu atravessamento.

22. Mas, afinal, como definir o "eu” na imitação/citação/representação xamânico-ritual? Qual o estatuto desse sujeito transposicional que atravessa e produz a travessia de mundos? Carlo Severi propôs, a partir desse "enunciador plural" (2008, p. 18), que o xamã "se torna uma 
espécie de representante da tradição, o que se poderia chamar um 'Eu-memória' por oposição ao simples indivíduo." (SEVERI, 2008, p. 12). Um eu-tradicional, ou eu-da-tradição, portanto. Como se sabe, traditio designava no direito romano uma das formas de aquisição da propriedade, a sua transmissão, e os malabarismos da personificação jurídica, e sua transformação medieval, a representação, serviam para garantir a continuidade do patrimônio a herança, transmissão do mesmo -, inclusive nos casos em que não havia mais "eu” (sujeito) algum. ${ }^{35}$ Nada mais distante do sujeito da enunciação xamânico-ritual, em que não se trata de transmitir uma mesmidade, mas de atravessar e aparentar diferenças: não um eu-tradicional, e sim um eu-tradiccional, (trans-)posição de entrecruzamento de dicções, discursos próprios e alheios, sobreposição de discursos diretos. ${ }^{36} \mathrm{O}$ eu-tradiccional não é um outro, mas um eu que se diz e se faz (dizendo) outro, um dizer eu que é um aparentar(-se) a outro.

\section{REFERÊNCIAS}

ALBERT, Bruce. A floresta poliglota. Tradução de Vinícius Alves. 2018. Disponível em: https://subspeciealteritatis.wordpress.com/2018/11/05/a-floresta-poliglota-bruce-albert/.

ARISTÓTELES. Poética. Edição bilíngue. Tradução, introdução e notas de Paulo Pinheiro. São Paulo: Editora 34, 2015.

\footnotetext{
${ }^{35}$ O locus em que se dá o debate medieval sobre a representação é a casuística, os casos de escola, reais ou imaginários (em torno dos quais se formou o corpo doutrinário do direito medieval), mais especificamente, os casos envolvendo sucessão patrimonial, que têm como centro, o caso extraordinário (e por isso mesmo paradigmático) de um monastério em que todos os seus monges teriam morrido: a quem caberia o seu patrimônio, então? Tratava-se, assim, de definir o modo de transmissão dos bens, das coisas, de estabelecer uma continuidade (fazer da traditio uma tradição). A partir dos debates, consolidou-se a hipótese da representação, da pessoa moral ou fictícia: "Os bens são revertidos provisoriamente a uma instância terceira, a saber, ao colégio como entidade. O colégio é tomado, assim, na qualidade de pessoa jurídica (...). O colégio concreto é duplicado no colégio abstrato, e este último é qualificado como pessoa. Além disso, essa 'pessoa' não é mais postulada somente nos casos extremos, nos quais se deve fazer recurso à figura personificada da herança jacente (...). A cidade ideal, a entidade personificada representa aqui não mais somente os mortos, mas a comunidade contínua de todos os que vivem e morrem. Esse duplo institucional é constante a tal ponto que, para postulá-lo, não é preciso nem mesmo mais a morte (...). Seja qual for o caso agora, uma dupla representação é necessária: a da comunidade pela sua pessoa, a da pessoa por seus órgãos, assembleias ou magistrados." (THOMAS, 2005, p. 68-69). Como vimos, a representação (e a pessoa jurídica) tem por substrato a ausência. Mas, se o caso extraordinário informa todos os demais, então a atribuição de personalidade jurídica ao legado no direito romano (caso excepcional máximo, em que o morto, as coisas do morto, funcionam como pessoas) revela que a pessoa, no direito ocidental, é que constitui um eu-tradicional, uma posição jurídico-enunciativa destinada a manter a transmissão e continuidade do mesmo. ${ }^{36}$ Por isso, o $e u$-tradiccional se situa nas antípodas do nós majestático: enquanto neste, um eu fala pelos outros, naquele são os outros que falam pelo eu (no duplo sentido de através de, ocupando sua posição e em seu nomes). Aquilo que Johansen chamou de "kinship I", o eu-de-parentesco, em que o sujeito se refere aos "feitos da sua linhagem ancestral durante várias gerações utilizando o pronome na primeira pessoa [do singular]." (SAHLINS, 2008, p. 37), está, assim, muito mais próximo de um eu-tradiccional do que de um Eu-memória, pois não indica uma unidade e totalidade prévias como o conceito de Severi parece implicar, mas, antes, que mais de um sujeito performativamente aparentados através da enunciação - diga eu, que mais de um eu (se) atravesse (n)o dizer.
} 
AUSTIN, J. L. Quando dizer é fazer: palavras e ação. Tradução de Danilo Marcondes de Souza Filho. Porto Alegre: Artes Médicas, 1990.

AUTHIER-REVUZ, Jacqueline. Heterogeneidade(s) enunciativa(s). Cadernos de Estudos Linguísticos, Campinas, v. 19, p. 25-42, 1990.

BANFIELD, Ann. Unspeakable Sentences: Narration and Representation in the Language of Fiction. Boston: Routledge \& Paul, 1982.

BENJAMIN, Walter. Passagens. Organização de Willi Bolle. Tradução de Irene Aron e Cleonice Paes Barreto Mourão. Belo Horizonte/São Paulo: Editora UFMG/Imprensa Oficial do Estado de São Paulo, 2006.

BENVENISTE, Émile. Problemas de linguística geral. I. 4. ed. Tradução de Maria da Glória Novak e Maria Luisa Neri. Campinas: Pontes/ Editora da UNICAMP, 1995.

BENVENISTE, Émile. Problemas de linguística geral. II. 2. ed. Tradução de Eduardo Guimarães. Campinas: Pontes, 2006.

CALHEIROS, Orlando. Aikewara: esboços de uma sociocosmologia tupi-guarani. 2014. Tese (Doutorado em Antropologia Social) - Museu Nacional, Universidade Federal do Rio de Janeiro, Rio de Janeiro, 2014.

CALHEIROS, Orlando. O próprio do desejo: a emergência da diferença extensiva entre os viventes (Aikewara, Pará). Cadernos de Campo, São Paulo, v. 24, p. 487-504, 2015.

CAMPOS, Haroldo de. Metalinguagem \& outras metas: ensaios de teoria e crítica literária. 4. ed. 1. reimp. São Paulo: Perspectiva, 2004.

CATREN, Gabriel. The Trans-Umweltic Express. 2016. Disponível em: http://www.glassbead.org/article/the-trans-umweltic-express/?lang=enview.

CESARINO, Pedro de Niemeyer. "Eventos ou textos? A pessoa múltipla e o problema da tradução das artes verbais Amazônicas". In: Daher, Andrea. (Org.) Oral por escrito: a oralidade na ordem da escrita, da retórica à literatura. Chapecó, Rio de Janeiro: Argos, EdUERJ, 2018.

CESARINO, Pedro de Niemeyer. De duplos e estereoscópios: paralelismo e personificação nos cantos xamanísticos ameríndios. Mana, Rio de Janeiro, v. 12, n. 1, p. 105-134, 2006.

CESARINO, Pedro de Niemeyer. Montagem e formação do mundo nas artes verbais marubo. Species - Revista de Antropologia Especulativa, Curitiba, v. 1, p. 66-78, 2015.

CESARINO, Pedro de Niemeyer. Oniska - poética do xamanismo na Amazônia. São Paulo: Perspectiva, FAPESP, 2011. 
COELHO DE SOUZA, Marcela. Cross-twins and outcestous marriages: How kinship (under)determines humanity for the Kĩsêdjê of central Brazil. In: PITARCH, Pedro; KELLY, José Antonio. The Culture of Invention in the Americas. Anthropological Experiments with Roy Wagner. Canon Pyon: Sean Kingston Publishing, 2018. p. 187-209.

CORTÁZAR, Julio. Valise de cronópio. Tradução de Davi Arriguci Jr. e João Alexandre Barbosa. Organização de Haroldo de Campos e Davi Arriguci Jr.. São Paulo: Perspectiva, 2008 .

COSTA LIMA, Luiz. Trilogia do controle: O controle do imaginário, Sociedade e discurso ficcional, O fingidor e o censor. 3. ed. revista. Rio de Janeiro: Topbooks, 2007.

CUNHA, Manuela Carneiro da; ALMEIDA, Mauro Barbosa de. (Org.). Enciclopédia da floresta - O Alto Juruá: práticas e conhecimento das populações. São Paulo: Companhia das Letras, 2002.

DERRIDA, Jacques. Essa estranha instituição chamada literatura. Tradução de Marileide Dias Esqueda. Belo Horizonte: Ed. UFMG, 2014.

DERRIDA, Jacques. Espectros de Marx: o estado da dívida, o trabalho do luto e a nova Internacional. Tradução de Anamaria Skinner. Rio de Janeiro: Relume-Dumará, 1994.

DOLEŽEL, Lubomír. Heterocosmica: Fiction and Possible Worlds. Baltimore: The John Hopkins Press, 2000.

GALVÃO, Walnice Nogueira. As formas do falso: um estudo sobre a ambiguidade em Grande Sertão: Veredas. São Paulo: Perspectiva, 1972.

GUIMARÃES ROSA, João. A benfazeja. In: GUIMARÃES ROSA, João. Primeiras estórias. Ed. eletrônica. Rio de Janeiro: Nova Fronteira, 2001.

HEURICH, Guilherme Orlandini. Música, morte e esquecimento na arte verbal Araweté. 2015. Tese (Doutorado em Antropologia Social) -Museu Nacional da Universidade Federal do Rio de Janeiro, Rio de Janeiro, 2015.

HORÁCIO. Arte poética. Edição bilíngue. Tradução, introdução e notas de Guilherme Gontijo Flores. Belo Horizonte: Autêntica, 2020.

KANTOROWICZ, Ernst H. The sovereignty of the artist: a note on legal maxims and renaissance theories of art. In: MEISS, Millard (ed.). Essays in honor of Erwin Panofsky. Nova Iorque: New York University Press, 1961. p. 267-279.

KELLY LUCIANI, José Antonio. Aprendendo sobre os diálogos cerimoniais Yanomami. Species - Revista de antropologia especulativa, Curitiba, v. 1, p. 45-65, 2015.

KELLY LUCIANI, José Antonio. Sobre a anti-mestiçagem. Tradução de Nicole Soares, Levindo Pereira e Marcos de Almeida Matos. Desterro/Curitiba: Cultura e Barbárie, species núcleo de antropologia especulativa, 2016. 
KOPENAWA, Davi; ALBERT, Bruce. A queda do céu: palavras de um xamã yanomami. Tradução de Beatriz Perrone-Moisés. São Paulo: Companhia das Letras, 2015.

LEMINSKI, Paulo. Poesia: a paixão da linguagem. In: CARDOSO, Sérgio et al. Os sentidos da paixão. [Curso promovido pelo núcleo de Estudos e Pesquisas da Fundação Nacional de Arte, em 1986]. São Paulo: Companhia das Letras, 1987. p. 283-291.

LÉVI-STRAUSS, Claude. O pensamento selvagem. Tradução de Tânia Pellegrini. Campinas: Papirus, 1989.

LÉVI-STRAUSS, Claude. A eficácia simbólica. In: LÉVI-STRAUSS, Claude. Antropologia estrutural. Tradução de Beatriz Perrone-Moisés. São Paulo: Cosac Naify201-220, 2008.

LIMA, Tânia Stolze. O dois e seu múltiplo: reflexões sobre o perspectivismo em uma cosmologia tupi. Mana, Rio de Janeiro, v. 2, n. 2, p. 21-47, 1996.

LIZOT, Jacques. Diccionario enciclopédico de la lengua yãnomãmi, con la colaboración de Hepëwë, Nõhõkuwë y Tiyetirawë. Tradução ao castelhano do manuscrito francês de Marie Gamondés Tulián, Ana Flora Reig e Francesca Lo Truglio. Puerto Ayacucho: Vicariato Apostólico de Puerto Ayacucho, 2004.

MAGDELAIN, Andre. Jus imperium auctoritas. Études de droit romain. Roma: École Française de Rome, 1990.

MATOS, Beatriz de Almeida. A Visita dos Espíritos: ritual, história e transformação entre os Matses da Amazônia brasileira. 2014. Tese (Doutorado em Antropologia Social) Museu Nacional da Universidade Federal do Rio de Janeiro, Rio de Janeiro, 2014.

MEINONG, Alexius. Teoría del objeto y Presentación personal. Tradução ao castelhano de Carola Pivetta. Estudo introdutório de Emanuele Coccia. Buenos Aires: Miño y Dávila, 2008.

NATALI, Marcos. Além da literatura. Literatura e sociedade, São Paulo, v. 11, n. 9, p. 30-43, 2006.

NODARI, Alexandre. Censura: ensaio sobre a "servidão imaginária". 2012. Tese (Doutorado em Literatura) - Universidade federal de Santa Catarina, Florianópolis, 2012.

NODARI, Alexandre. Juridiquês. sopro, São Paulo, v. 83, p. 7-12, 2013.

NODARI, Alexandre. A metamorfologia de Macunaíma: notas iniciais. Crítica cultural, Cachoeirinha, v. 15, n. 1, p. 41-67, 2020a.

NODARI, Alexandre. Alterocupar-se: obliquação e transicionalidade na experiência literária. Estudos de literatura brasileira contemporânea, Brasília, v. 57, p. 1-17, 2019.

NODARI, Alexandre. A (outra) gente: multiplicidade e interlocução no Grande sertão: veredas. O eixo e a roda, Belo Horizonte, v. 27, n. 3, p. 29-61, 2018. 
NODARI, Alexandre. A literatura como antropologia especulativa. Revista da ANPOLL, Campinas, v. 38, p. 75-85, 2015.

NODARI, Alexandre. Quase-evento: sobre a estoricidade da experiência literária. e-lyra, Porto, v. 10, p. 55-77, 2017.

NODARI, Alexandre. A tradução da/dá origem: notas sobre mito, romance e encontro de mundos. Belas Infiéis, v. 9, n. 2, p. 83-94, 2020 b.

ORTEGA Y GASSET, José. A idéia do teatro. Tradução de J. Guinsburg. São Paulo: Perspectiva, 1991.

PATTERSON, Annabel. Censorship and Interpretation. The conditions of writing and reading in early modern England. Madison: University of Winsconsin Press, 1991.

PAVEL, Thomas G. Fictional worlds. Cambridge: Harvard University Press, 1986.

PIMENTA, Alberto. Liberdade e aceitabilidade da obra de arte literária. Colóquio Letras, Lisboa, v. 32, p. 5-14, 1976.

PLATÃO. República. Tradução e organização de J. Guinsburg (A República de Platão. Obras I). São Paulo: Perspectiva, 2016.

PLATÃO. Íon. Edição bilíngue. Introdução, tradução e notas de Cláudio Oliveira. Belo Horizonte: Autêntica Editora, 2011.

RÓNAI, Paulo. Os vastos espaços. In: GUIMARÃES ROSA, João. Primeiras estórias. Ed. eletrônica. Rio de Janeiro: Nova Fronteira, 2001.

SÁ, Lúcia. Histórias sem fim: perspectivismo e forma narrativa na literatura indígena da Amazônia. Tradução de Pedro Craveiro. Itinerários, São Paulo, v. 51, p. 157-178, 2020.

SAHLINS, Marshall. Metáforas históricas e realidades míticas: estrutura nos primórdios da história no reino das ilhas Sandwich. Tradução de Fraya Frehse. Rio de Janeiro: Jorge Zahar, 2008.

SEEGER, Anthony. Por que cantam os Kĩsêdjê: uma antropologia musical de um povo amazônico. Tradução de Guilherme Werlang. São Paulo: Cosac Naify, 2015.

SEVERI, Carlo. El Yo-memoria: Una nueva aproximación a los cantos chamánicos amerindios. Tradução de Saúl Millán. Cuicuilco, Cidade do México, v. 15, n. 42, p. 11-28, 2008.

SHELL, Marc. Money, language and thought: literary and philosophic economies from medieval to the modern era. Baltimore: John Hopkins University Press, 1993.

STERZI, Eduardo. Hipóteses. METEÖRO - revista de poesia, [s. l.], v. 1, p. 249-257, 2019. 
STIERLE, Karlheinz. A ficção. Tradução de Luiz Costa Lima. Rio de Janeiro: Caetés, 2006.

TEDLOCK, Denis. Learning to Listen: Oral History as Poetry. boundary 2, [s. l.], v. 3, n. 3, p. 707-728, 1975.

THOMAS, Yan. Fictio legis. L'empire de la fiction romaine et ses limites médiévales. Droits, [s. l.], v. 21, p. 17-63, 1995.

THOMAS, Yan. L'extrême et l'ordinaire. Remarques sur le cas médiéval de la communauté disparue. In: PASSERON, Jean-Claude; REVEL, Jacques (eds.). Penser par cas. Paris:

Éditions de l'École des hautes études en sciences sociales, 2005. p 45-73.

THOMAS, Yan. Le sujet de droit, la personne et la nature. Sur la critique contemporaine du sujet de droit. Le Débat, Paris, v. 100, n. 3, p. 85-107, 1998.

TOWNSLEY, Graham. Song paths: The Ways and Means of Yaminahua Shamanic Knowledge. L'Homme, Paris, v. 33, n. 126-128, p. 449-468, 1993.

VIVEIROS DE CASTRO, Eduardo. Perspectival Anthropology and the Method of Controlled Equivocation. Tipití, [s. l.], v. 2, n. 1, p. 3-22, 2004.

VIVEIROS DE CASTRO, Eduardo. Metafísicas canibais: elementos para uma antropologia pós-estrutural. São Paulo: Cosac Naify, n-1 edições, 2015.

VIVEIROS DE CASTRO, Eduardo. A inconstância da alma selvagem e outros ensaios de antropologia. São Paulo: Cosac Naify, 2002.

VIVEIROS DE CASTRO, Eduardo. Cosmological Deixis and Amerindian Perspectivism. The Journal of the Royal Anthropological Institute, v. 4, n. 3, p. 469-488, 1998.

VIVEIROS DE CASTRO, Eduardo. Araweté - os deuses canibais. Rio de Janeiro: Jorge Zahar/ANPOCS, 1986.

VIVEIROS DE CASTRO, Eduardo. Encontros. Organização de Renato Sztutman. Rio de Janeiro: Beco do Azougue, 2008.

WAGNER, Roy. Habu: the Innovation of Meaning in Daribi Religion. Chicago: The University of Chicago Press, 1972.

Submetido em: 16 set. 2021.

Aceito em: 17 set. 2021.

DOI: https://dx.doi.org/10.22456/2238-8915.118511 